\title{
Competing for Capital: The Diffusion of Bilateral Investment Treaties, 1960-2000
}

\section{Citation}

Elkins, Zachary, Andrew T. Guzman, and Beth A. Simmons. 2006. Competing for capital: The diffusion of bilateral investment treaties, 1960-2000. International Organization 60(4): 811-846

\section{Published Version}

http://dx.doi.org/10.1017/S0020818306060279

\section{Permanent link}

http://nrs.harvard.edu/urn-3:HUL.InstRepos:3017499

\section{Terms of Use}

This article was downloaded from Harvard University's DASH repository, and is made available under the terms and conditions applicable to Other Posted Material, as set forth at http:// nrs.harvard.edu/urn-3:HUL.InstRepos:dash.current.terms-of-use\#LAA

\section{Share Your Story}

The Harvard community has made this article openly available.

Please share how this access benefits you. Submit a story.

Accessibility 


\title{
Competing for Capital: The Diffusion of Bilateral Investment Treaties, 1960-2000
}

\author{
Zachary Elkins, Andrew T. Guzman, \\ and Beth A. Simmons
}

\begin{abstract}
Over the past forty-five years, bilateral investment treaties (BITs) have become the most important international legal mechanism for the encouragement and governance of foreign direct investment. The proliferation of BITs during the past two decades in particular has been phenomenal. These intergovernmental treaties typically grant extensive rights to foreign investors, including protection of contractual rights and the right to international arbitration in the event of an investment dispute. How can we explain the widespread adoption of BITs? We argue that the spread of BITs is driven by international competition among potential host countries-typically developing countries-for foreign direct investment. We propose a set of hypotheses that derive from such an explanation and develop a set of empirical tests that rely on network measures of economic competition as well as more indirect evidence of competitive pressures on the host to sign BITs. The evidence suggests that potential hosts are more likely to sign BITs when their competitors have done so. We find some evidence that coercion and learning play a role, but less support for cultural explanations based on emulation. Our main finding is that the diffusion of BITs is associated with competitive economic pressures among developing countries to capture a share of foreign investment. We are agnostic at this point about the benefits of this competition for development.
\end{abstract}

The global market for productive capital is more integrated than ever before. The growth of foreign direct investment (FDI) is a clear example. According to World Bank data, gross FDI as a percentage of total world production increased sevenfold from 1.2 percent to 8.9 percent between 1970 and 2000. Though such investments tend to be highly skewed across jurisdictions—developed countries account

For useful comments on earlier drafts of this article, we thank Bill Bernhard, Bear Braumoeller, Frank Dobbin, Robert Franzese, Jeffry Frieden, Geoffrey Garrett, Tom Ginsburg, Jude Hays, Lisa Martin, Bob Pahre, Mark Ramsayer, Steven Ratner, Susan Rose-Ackerman, and John Sides. For research assistance, we thank Elizabeth Burden, Raechel Groom, and Alexander Noonan. 
for more than 93 percent of outflows and 68 percent of inflows ${ }^{1}$ - foreign capital has come to play a much more visible role in many more countries worldwide.

It is widely recognized that economic globalization requires market-supporting institutions to flourish. But unlike trade and monetary relations, virtually no multilateral rules for FDI exist. ${ }^{2}$ Direct investments in developing countries are overwhelmingly governed by bilateral investment treaties (BITs). BITs are agreements establishing the terms and conditions for private investment by nationals and companies of one country in the jurisdiction of another. Virtually all BITs cover four substantive areas: FDI admission, treatment, expropriation, and the settlement of disputes. These bilateral arrangements have proliferated over the past forty-five years, and especially in the past two decades, even as political controversies have plagued efforts to establish a multilateral regime for FDI.

Why the profusion of bilateral agreements? The popularity of BITs contrasts sharply with the collective resistance developing countries have shown toward proinvestment principles under customary international law and the failure of the international community to make progress on a multilateral investment agreement. ${ }^{3}$ On its face, this seems to suggest that BITs do not simply reflect the ready acceptance of dominant international property rights norms. Our theory and findings support the competitive economic explanations described in the introduction to this symposium: ${ }^{4}$ the proliferation of BITs—and the liberal property rights regime they embody-is propelled in good part by the competition among potential host countries for credible property rights protections that direct investors require.

The article is organized as follows. The first section describes the spread of BITs in some detail. The second section presents a model of competition for investment that could lead to diffusion among competitors. The third section discusses the methods we use to test our propositions (and a range of alternatives), and the fourth section discusses our findings. Our data are consistent with competitive pressures for BIT proliferation: governments are influenced by competitors' policies and by the mobility of FDI in manufactures, which tends to intensify competition among hosts. We interpret our findings as evidence of pressure for certain governments to adopt capital-friendly policies in highly competitive global capital markets.

\section{Securing Investors' Legal Rights}

\section{From Customary Law to Bilateral Investment Treaties}

FDI has always been subject to contractual and political hazards that raise the expected costs of investing. ${ }^{5}$ Before the use of BITs, few mechanisms existed to

1. UNCTAD. FDI/TNC Database. Available at 〈http://www.unctad.org $\rangle$. Accessed 20 June 2006.

2. For a review of the relevant legal literature, see Dolzer 1981; Minor 1994; Sornarajah 1994; and Vagts 1987.

3. Guzman 1998.

4. Simmons, Dobbin, and Garrett, this volume.

5. Henisz 2000. 
make state promises about the treatment of foreign investment credible. ${ }^{6}$ Customary international law, expressed succinctly in the "Hull Rule," held that "no government is entitled to expropriate private property, for whatever purpose, without provision for prompt, adequate, and effective payment therefore."7 Apart from the obvious problem of enforcement, this approach did not allow potential hosts to voluntarily signal their intent to contract in good faith.

Both customary international law and its practice were under attack by developing country hosts by the 1950s. The nationalization of British oil assets by Iran in 1951, the expropriation of Liamco's concessions in Libya in 1955, and the nationalization of the Suez Canal by Egypt a year later served notice of a new militancy on the part of investment hosts. The nationalization of sugar interests by Cuba in the 1960s further undercut assumptions about the security of international investments. ${ }^{8}$ Meanwhile, collective resistance to the Hull Rule in the United Nations was on the rise. In 1962, the UN General Assembly adopted the "Resolution on Permanent Sovereignty over Natural Resources" that provided for merely "appropriate" compensation in the event of expropriation. Several more UN resolutions followed in the 1970 s, ${ }^{9}$ along with a string of undercompensated expropriations around the world. ${ }^{10}$

Bilateral treaties made their debut in the late 1950s, just as consensus on customary rules began to erode. BITs were innovative in a number of respects. ${ }^{11}$ They

6. For a discussion of the historical protection of foreign investment, see Lipson 1985.

7. See Cordell Hull's note to the Mexican Minister of Foreign Affairs during a 1938 dispute over land expropriations, reprinted in Green H. Hackworth, Digest of International Law v. 3, § 228 (1942). The Rule itself predates Cordell Hull's statement, and various statements of it can be found in decisions from the early part of the twentieth century. See Concerning the Factory at Chorzow (Ger. v. Pol.), 1926-29 P.C.I.L. (ser. A), Nos. 7, 9, 17, 19; and Norwegian Shipowners Claims Arbitration (U.S. v. Nor.) 1 Rep. Int'l Arb. Awards 307 (1922).

8. Guzman 1998.

9. These are discussed in Lipson 1985. In 1966 the General Assembly reaffirmed states' rights to nationalize resources without reference to international legal principles. In 1972, the UN General Assembly passed Resolution 3041 (XXVII), which contained an endorsement of the Trade and Development Board's resolution 88 (XII) of 19 October 1972, regarding permanent sovereignty over natural resources, and claimed that compensation for natural resource nationalization cases was to be fixed by the nationalizing state, with jurisdiction for such cases falling within the sole jurisdiction of the nationalizing country's courts. The 1973 Resolution on Permanent Sovereignty over Natural Resources (Resolution 3171) stated that in the event of nationalization "each State is entitled to determine the amount of possible compensation and the mode of payment." The 1974 Charter of Economic Rights and Duties of States [GA Res. 3281(xxix), UN GAOR, 29th Sess., Supp. No. 31, 50] specified the right of each state "To nationalize, expropriate or transfer ownership of foreign property, in which case appropriate compensation should be paid by the State adopting such measures, taking into account its relevant laws and regulations and all circumstances that the State considers pertinent," with national courts taking jurisdiction in case of disputes [Art. 2(c)].

10. See Kobrin 1980.

11. Other mechanisms have been used to try to protect foreign investment, of course. One possibility since 1988 is to apply for insurance through the World Bank's Multilateral Insurance Guarantee Agency (MIGA). MIGA covers risks associated with transfer restriction, expropriation, breach of contract, and risks relating to war and civil disturbances. See $\langle\mathrm{http}: / /$ www.miga.org $/\rangle$. Accessed 20 June 2006. U.S. businesses can also insure against risks associated with currency inconvertibility, expropriation, and political violence by applying for investment insurance from the Overseas Private Investment Corporation (OPIC), a U.S. government agency. See $\langle$ http://www.opic.gov/Insurance/ $\rangle$. Accessed 20 June 2006. 
require an explicit commitment on the part of the potential host government and involve direct negotiations with the government of potential investors. In this way, BITs up the political ante for the host government and raise expectations of performance. The typical BIT offers a wider array of substantive protections than did the customary rule. For example, BITs typically require national treatment and most-favored-nation treatment of foreign investments in the host country, ${ }^{12}$ protect contractual rights, ${ }^{13}$ guarantee the right to transfer profits in hard currency to the home country, and prohibit or restrict the use of performance requirements. ${ }^{14}$ Finally, and perhaps most importantly, BITs provide for international arbitration of disputes between the investor and the host country ${ }_{1}^{15}$ typically through the International Center for Settlement of Investment Disputes (ICSID) or the UN Commission on International Trade Law (UNCITRAL).

\section{The Spread of BITs}

Despite the aggressive campaign waged by some developing countries against the relevant customary international law, BITs were embraced by many potential host governments. ${ }^{16}$ Figure 1 documents the geometric growth of both investment treaties and mean inflows of FDI as a percentage of GDP from 1960 to 2000. Early BITs typically involved a midsized European power and one of the least developed countries, often in Africa (see Table 1). The negotiation of BITs proceeded at a moderate pace until the mid-1980s, rarely exceeding twenty new treaties per year. Late in the decade, however, the rate of signings accelerated dramatically, with an average of more than one hundred new treaties a year throughout the 1990s.

The United States embraced BITs later than did its West European counterparts. Between 1962 and 1972, during which time West Germany entered into forty-six BITs and Switzerland entered into twenty-seven, the United States eschewed such treaties and signed only two Friendship Commerce and Navigation Treaties-with Togo and Thailand. ${ }^{17}$ One reason for the delayed U.S. participation in bilateral arrangements may have been the hope of retaining a multilateral approach. The United States was one of the most aggressive proponents of the Hull Rule and

12. For example, the 1994 U.S. Prototype Bilateral Investment Treaty, Office of the Chief Counsel for International Commerce, U.S. Department of Commerce; Article 2(1), 2(2) (a). For convenience, throughout this article we label the more developed partner in a BIT the "home" country (meaning the home of investors) and the less-developed partner the "host." The treaty obligations bind both parties, but in the vast majority of treaties there is a developed country that will be the source of most FDI and a developing country that will be the recipient.

13. For example, 1994 U.S. Prototype BIT, Article I(d)(ii).

14. For example, ibid., Article V(1-2).

15. For example, ibid., Article IX.

16. It is interesting to note, however, that some of the most vociferous opponents of the Hull Rule were in fact latecomers to the BITs movement. As of the late 1990s, Mexico for example had signed only two BITs, with Spain and Switzerland. Brazil did not sign a BIT until 1994, and as of the late 1990s none of its 10 bilateral agreements had entered into force. India's pattern is similar to that of Brazil. See 〈http://www.worldbank.org/icsid/treaties/treaties.htm〉. Accessed 10 December 2003.

17. Vandevelde 1988. 


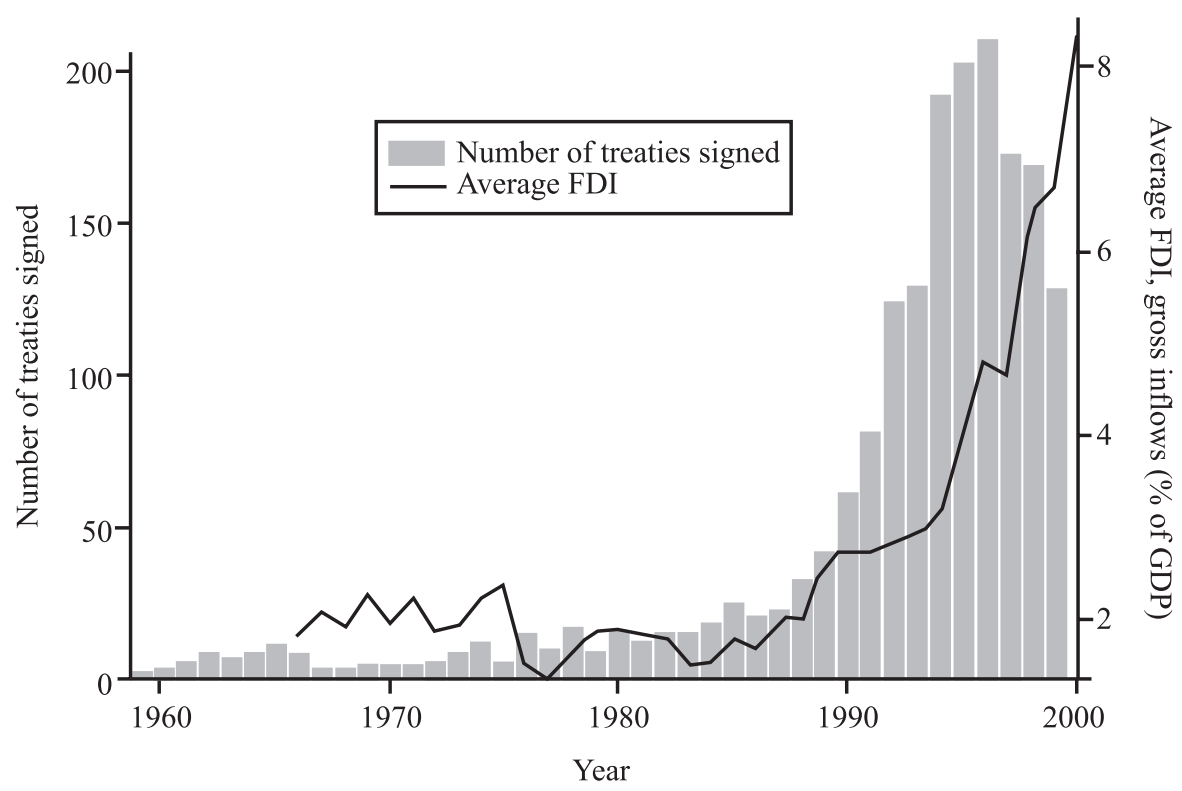

FIGURE 1. Number of bilateral investment treaties signed and mean global foreign direct investment as a proportion of GDP, by year, 1959-99

may have feared that BITs represented a threat to its claim that investment was already protected under customary international law. Moreover, potential hosts may have had incentives to resist the relatively onerous provisions the U.S. government typically tried to secure. One of the prime differences between the terms typically offered by the Europeans and the United States at this time was the former's emphasis on investment protection and the latter's additional insistence on liberalization. ${ }^{18}$

It was not until 1981 that the United States changed its view on BITs. There is evidence that some officials in the administration of U.S. President Ronald Reagan viewed BITs as an alternative way to protect the principles contained in the embattled Hull Rule. Secretary of State George Schultz argued that BITs were designed "to protect investment not only by treaty but also by reinforcing traditional international legal principles and practice regarding foreign direct private invest-

18. "Multilateral or Bilateral Investment Negotiations: Where Can Developing Countries Make Themselves Heard" Briefing Paper No. 9. Available at 〈http://cuts-international.org/9-2002.pdf . Accessed 12 July 2006. Some observers note that the insistence on liberalization explains the inability of the United States to secure agreements with East and Southeast Asian countries until quite recent years; see Reading 1992. 
TABLE 1. The first forty bilateral investment

treaties signed

\begin{tabular}{|c|c|c|}
\hline Investing country & Host country & Year BIT signed \\
\hline Germany & Dominican Republic & 1959 \\
\hline Germany & Pakistan & 1959 \\
\hline Germany & Malaysia & 1960 \\
\hline Germany & Greece & 1961 \\
\hline Switzerland & Tunisia & 1961 \\
\hline Germany & Togo & 1961 \\
\hline Germany & Thailand & 1961 \\
\hline Germany & Liberia & 1961 \\
\hline Germany & Morocco & 1961 \\
\hline Switzerland & Niger & 1962 \\
\hline Switzerland & Cote d'Ivoire & 1962 \\
\hline Switzerland & Guinea & 1962 \\
\hline Germany & Cameroon & 1962 \\
\hline Switzerland & Congo & 1962 \\
\hline Switzerland & Senegal & 1962 \\
\hline Germany & Guinea & 1962 \\
\hline Germany & Turkey & 1962 \\
\hline Germany & Madagascar & 1962 \\
\hline Switzerland & Rwanda & 1963 \\
\hline Netherlands & Tunisia & 1963 \\
\hline Switzerland & Liberia & 1963 \\
\hline Switzerland & Cameroon & 1963 \\
\hline Germany & Sri Lanka & 1963 \\
\hline Germany & Tunisia & 1963 \\
\hline Germany & Sudan & 1963 \\
\hline Italy & Guinea & 1964 \\
\hline Switzerland & Togo & 1964 \\
\hline Germany & Senegal & 1964 \\
\hline Germany & Niger & 1964 \\
\hline Switzerland & Madagascar & 1964 \\
\hline Belgium-Luxembourg & Tunisia & 1964 \\
\hline Germany & Korea & 1964 \\
\hline Switzerland & Tanzania & 1965 \\
\hline Switzerland & Malta & 1965 \\
\hline Germany & Sierra Leone & 1965 \\
\hline Switzerland & Costa Rica & 1965 \\
\hline Germany & Ecuador & 1965 \\
\hline Netherlands & Cameroon & 1965 \\
\hline Netherlands & Cote d'Ivoire & 1965 \\
\hline Sweden & Cote d'Ivoire & 1965 \\
\hline
\end{tabular}

ment." 19 By the mid-1980s, the United States pursued investor protection in the same fashion as did the Europeans. Schultz noted in his communication with the

19. George P. Schultz, transmission letter to the president recommending transmission of the U.S.Turkey Bilateral Investment Treaty, 1985. Available at 〈http://www.state.gov/documents/organization/ 43615.pdf $\rangle$. Accessed 12 July 2006. 


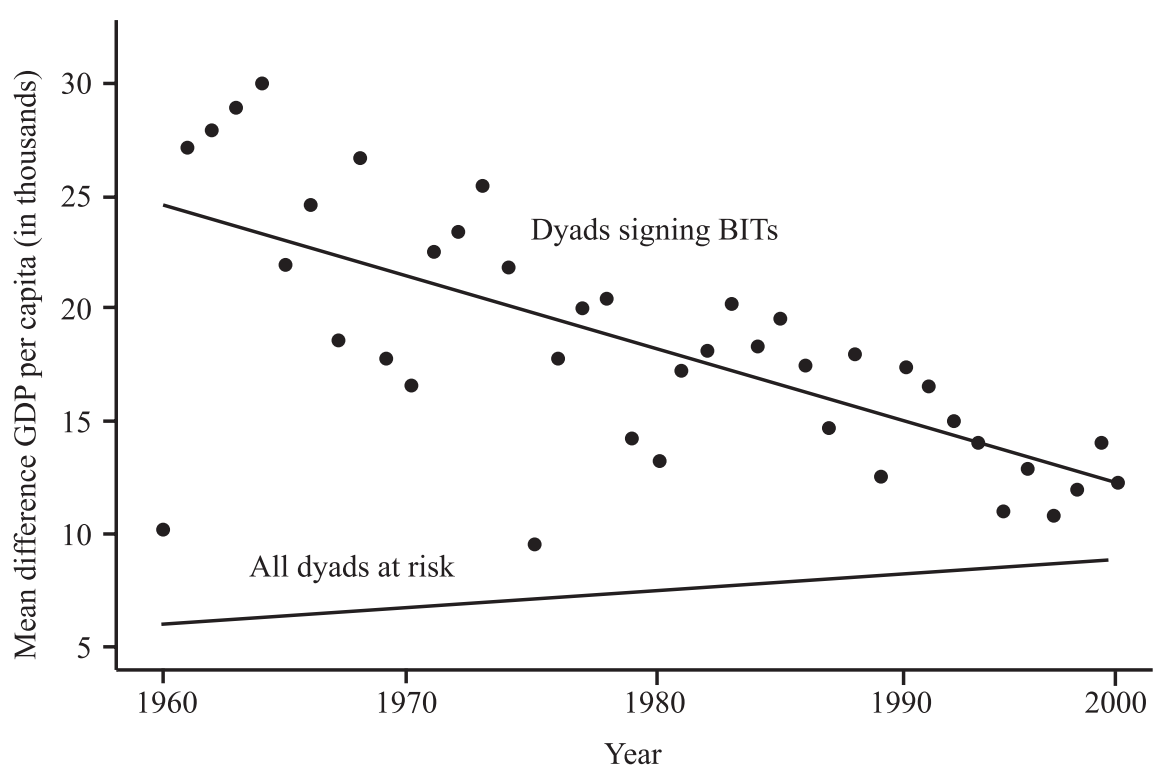

Note: Data points shown are for dyads signing BITs.

FIGURE 2. Mean difference in GDP per capita between dyad members

president after completion of six BITs in $1986^{20}$ that, "[o]ur BIT approach followed similar programs that had been undertaken with considerable success by a number of European countries, including the Federal Republic of Germany and the United Kingdom, since the early 1960s." ${ }^{21}$ By the late 1980s, most analysts would agree that governments in countries home to large multinational corporations (MNCs) had nearly converged on a single treaty model. Developing countries could, increasingly, opt to take it or to leave it. As Figure 1 attests, many did the former.

Early on, BITs were primarily agreements between countries of starkly varying developmental levels and political traditions. Figure 2, which plots the mean difference in gross domestic product (GDP) per capita between BIT partners as well as that between states in all other dyads "at risk" of signing in a given year, demonstrates that the economic differences within these dyads have declined fairly substantially over time, even while the wealth disparities between non-BIT dyads have increased. As is the case with wealth, the "political gap" between new BIT signers has also diminished significantly over the past thirty years. Figure 3 plots the mean difference in the level of democracy (as measured by Polity scores) of

20. Turkey, Morocco, Haiti, Panama, Senegal, and Zaire.

21. George P. Schultz, transmission letter to the president recommending transmission of the U.S.-Turkey Bilateral Investment Treaty, 1985. Available at〈http://www.state.gov/documents/ organization/43615.pdf $\rangle$. Accessed 12 July 2006. 


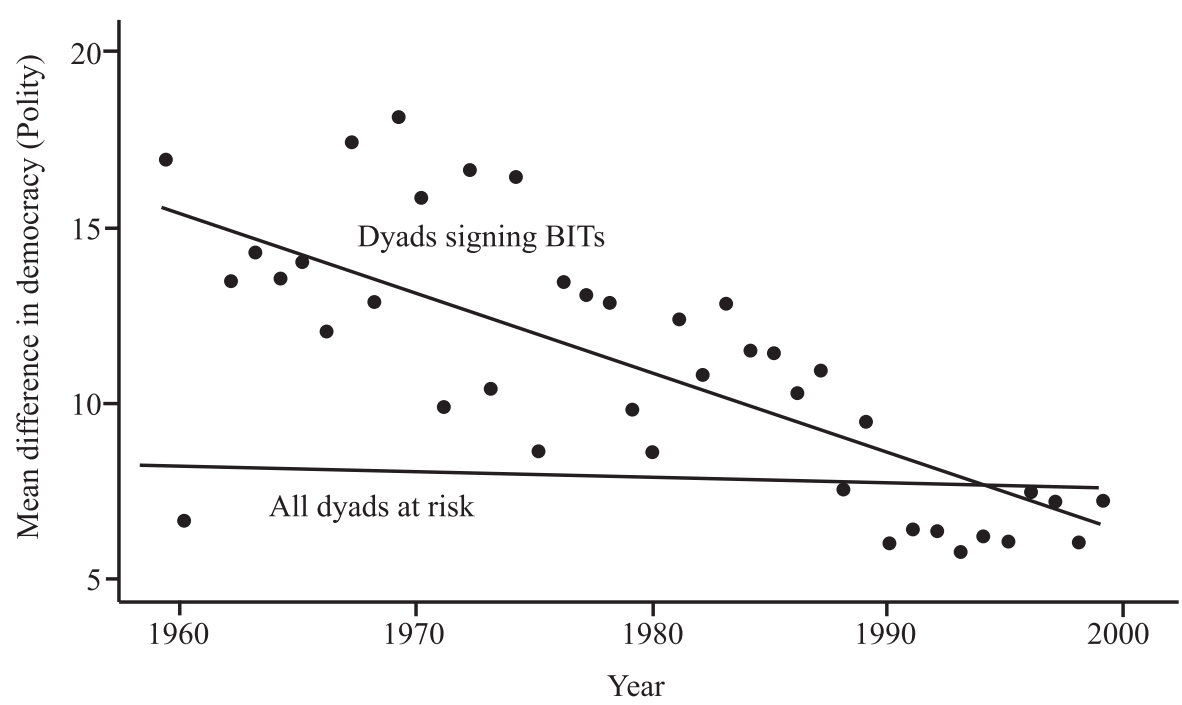

Note: Universe consists of states with more than 1 million inhabitants between 1960 and 1999. Data points shown are for dyads signing BITs.

FIGURE 3. Mean difference in democracy between dyad members

BIT partners in the year of their signing against that of all other dyads at risk of signing. Over time, new BIT partners have become more similar, evidence that the institution is spreading to a population of dyads of similar political and economic structure and, presumably, with less reason to sign such agreements.

By the late 1990s, there emerged a few twists to the basic theme of wealthy countries picking off potentially lucrative but risky venues one at a time. From about 1999, developing countries began a rather more proactive effort to create bilateral investment treaties among themselves. These activities have been coordinated through the UN Conference on Trade and Development (UNCTAD), and sometimes with the assistance of a major capital exporting country, such as Germany or France. During a meeting jointly sponsored by UNCTAD, the Swiss government, and a group of fifteen developing countries (G-15), seven developing countries signed eight bilateral treaties among themselves. ${ }^{22}$ Individual developing countries soon began to seize the initiative. At the request of Thailand, a minilateral conference yielded seven more developing country BITs, ${ }^{23}$ and furthered discussions on several more. Bolivia (2000), India (2001), and Croatia (2001) initiated minilateral discussions on a similar model. France financed a round of

22. Egypt, India, Indonesia, Jamaica, Malaysia, Sri Lanka, and Zimbabwe.

23. Thailand-Zimbabwe, Thailand-Croatia, Thailand-Iran, Zimbabwe-Croatia, Zimbabwe-Sri Lanka, Croatia-Iran, Thailand-Kazakhstan, Zimbabwe-Kazakhstan, and Croatia-Kazakhstan. Sweden also participated and concluded a BIT with Thailand. 
discussions primarily among the Francophone countries in 2001 that attracted twenty participants and yielded forty-two BITs, many of which involved noncontiguous, poor, highly indebted African countries for which it is difficult to imagine much benefit. (What are the chances that capital from Burkina Faso would flow to Chad, or investors from Benin would soon demand entrée to Mali?) More understandable, from an economic point of view, was the German-funded and supported meeting in October 2001 that drew together seven capital-poor countries (five of which were officially "highly indebted poor countries") and four wealthy European countries, ${ }^{24}$ yielding both understandable (Belgium-Cambodia) and bizarre (SudanZambia) bilateral treaty combinations. ${ }^{25}$ This recent turn toward BITs between developing states is more difficult for our theory to explain. It does seem to suggest that more political or sociological explanations may be increasingly relevant quite recently in some regions. However, these cases are still relatively few and of such recent vintage that they do not affect the broader relationships we report below.

\section{Leaders and Followers in BIT Agreements}

BITs present potential benefits for both capital-exporting and capital-importing countries. But which group of countries initiates and drives the signing of such agreements? Our theory, to anticipate the following section, assumes that potential host countries have an important (although not exclusive) role in initiating or nurturing BIT negotiations. Is this a plausible assumption? After all, powerbased theories-or "coercive" theories in the language of Simmons, Dobbin, and Garrett ${ }^{26}$ — suggest that dominant capital-exporting countries such as Germany or the United States control the agenda and begin BIT negotiations according to their schedule and needs. Indeed, the chronology described above suggests that some home countries establish BIT "programs" and sign agreements with a slate of developing countries in concentrated periods of time.

If the dominant powers determine the BIT schedule, then we should see evidence of home country "programs" when we look at BITs, by country, across time. Programs would look like clusters, or peaks, of activity in certain eras in a home country's history. By the same logic, if host countries take a lead role in producing BITs, their histories would also show some evidence of concerted, programmatic activity. Figure 4 and Figure 5 chart the number of BITs signed since 1959 for the twelve most active BIT signatories from both home (Figure 4) and host (Figure 5) countries. It appears that most home countries have BIT activity that

24. Participants included Cambodia, Eritrea, Malawi, Mozambique, Sudan, Uganda, and Zambia. Upon the request of these countries, Belgium, France, the Netherlands, and Sweden were both invited to participate and responded affirmatively.

25. Notice that even multilateral meetings of this sort have not yielded multilateral treaties on investment. The states involved have always chosen instead to sign a series of BITs. The question of why multilateral approaches are not adopted is interesting, but we leave it for another day.

26. Simmons, Dobbin, and Garrett, this volume. 

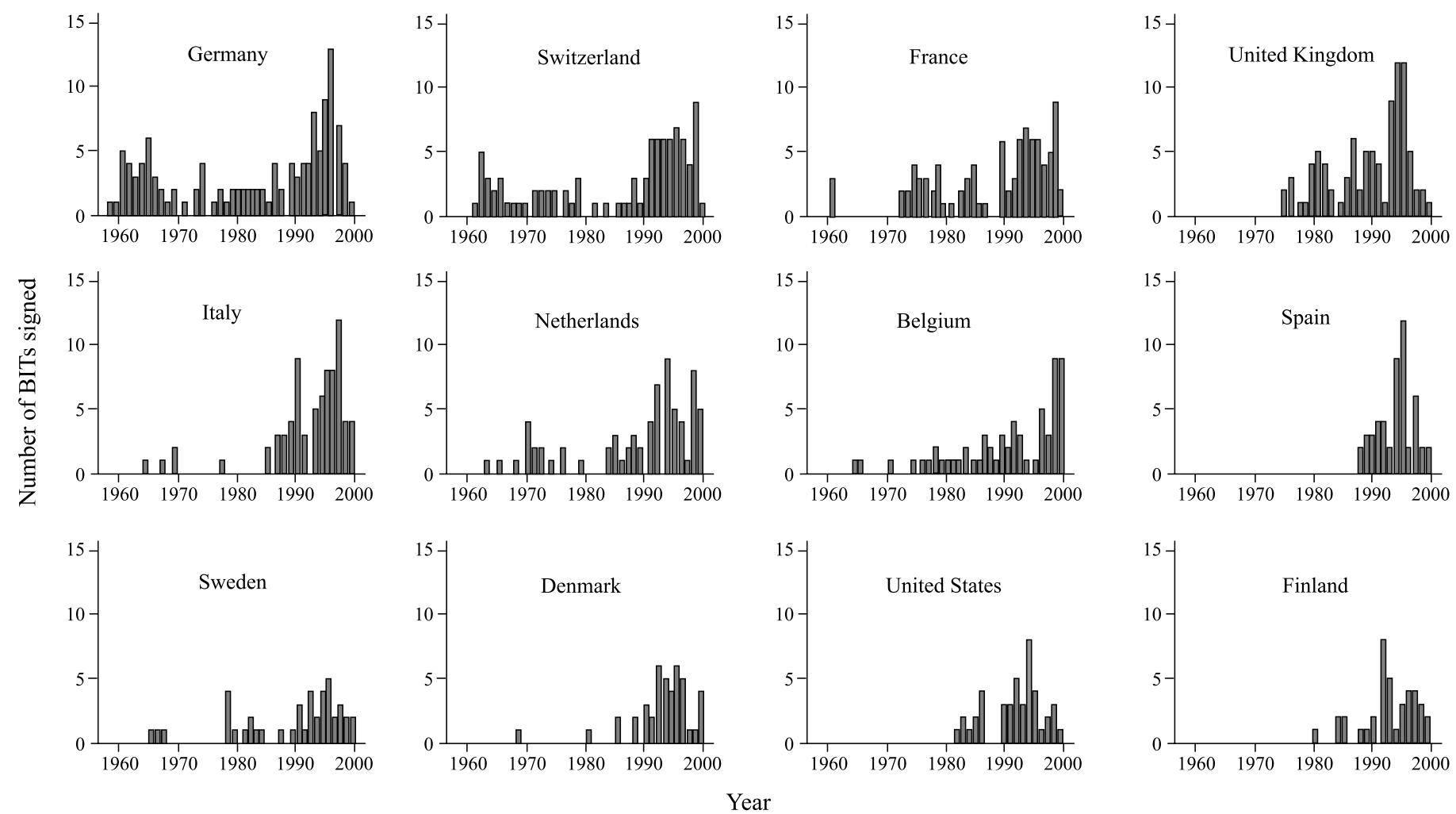

Note: Figure includes twelve most active BIT signers of capital-exporting countries.

FIGURE 4. Number of BITs signed, by country, 1959-99 

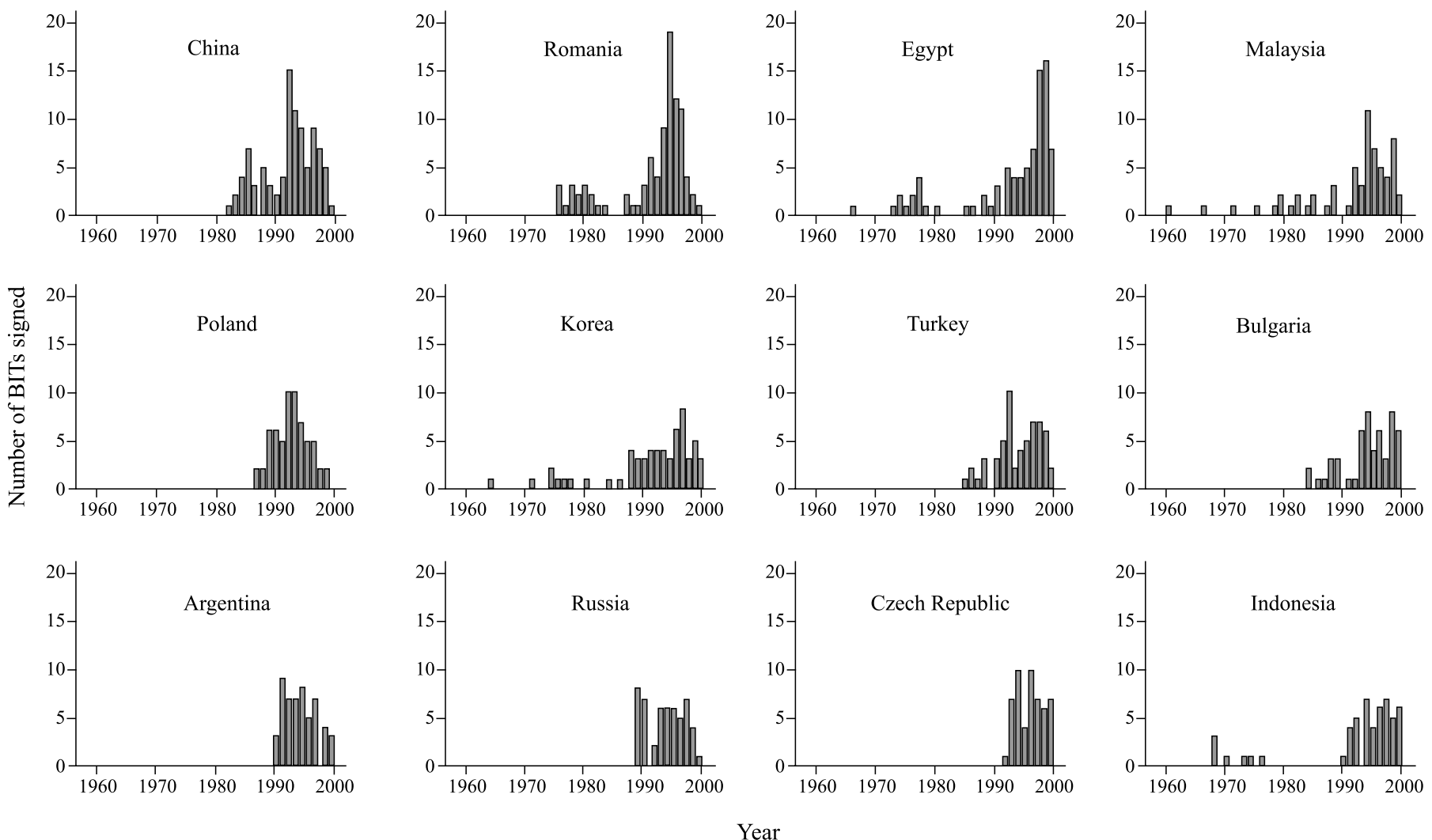

Note: Figure includes twelve most active BIT signers of capital-importing countries.

FIGURE 5. Number of BITs signed, by country, 1959-99 
lasts at least twenty years; most of these countries, in fact, sign BITs throughout the forty-year period. Spain is an exception, with a short spate of BITs in the 1990s only. Potential hosts, however, demonstrate a different pattern: their BIT signings spike up in a more clustered pattern, one indicative of programmatic activity (see Figure 5). ${ }^{27}$

Evidence of programmatic activity can be established statistically as well. Comparing the average kurtosis ${ }^{28}$ for the historical distribution of BITs among both home and host countries, it is clear that the distribution of BITs over the past forty years is significantly more peaked (less uniform) for the host than it is for home countries (9.11 and 4.48, respectively). The standard deviation of their distributions over time is also lower for host countries than it is for home $(7.08$ versus 9.39, respectively), suggesting a more clustered pattern of activity for the host. If BITs are driven by home country programs, it is not especially apparent in the data. Rather, it appears that potential hosts are more likely to sign in clusterssuggesting that while the major capital exporters stand ready with model treaties in hand, the decision whether and when to sign is left to a large extent to the host.

The notion that home countries make take-it-or-leave-it offers to potential hosts and that hosts eventually decide to sign BITs is also consistent with the observed content of BITs. These treaties tend to provide consistent terms, even across different home countries. In particular, the core terms of the treaties are almost always present: mandatory dispute resolution before an international arbitration body, a private right of action for investors, monetary compensation in the event of a violation, national treatment, and most-favored-nation treatment. This uniformity suggests that host countries are "price-takers" with respect to the terms of these treaties, consistent with our assumptions. In essence, each home country has market power over the terms that will govern investment by its locals. Host countries, on the other hand, realize that they must compete with other potential hosts and, therefore, cannot demand changes to the core provisions of the treaties.

\section{A Competitive Theory of BIT Diffusion}

Our theory of BIT diffusion ${ }^{29}$ has a simple structure. BITs are viewed by host governments and by investors as devices that raise the expected return on investments. The treaties do this by assisting governments in making credible commitments to treat foreign investors "fairly" —as described in the previous section. BITs

27. Appendixes 1 and 2, available online at $\langle$ https://netfiles.uiuc.edu/zelkins/www $\rangle$, also organized by capital-exporting and -importing countries, summarize the BIT history for all 178 countries that have ever signed a BIT.

28. Kurtosis is the degree to which a distribution is peaked, or clustered, with high kurtosis indicating clustered data, and low kurtosis indicating a more uniform distribution.

29. See Elkins and Simmons 2005, for a further elaboration of the concept of "diffusion." 
give host governments a competitive edge in attracting capital ${ }^{30}$ if there are otherwise doubts about their willingness to enforce contracts fairly. Accordingly, governments with little inherent credibility are more likely to sign BITs than are governments known for their fair treatment of foreign capital. The result is a competitive dynamic among potential hosts to reduce the risks and enhance the profitability of investing.

\section{BITs as a Credible Commitment}

Governments may have many motives to sign a BIT, but the most significant is to make a credible commitment to treat foreign investors fairly. BITs allow governments to make credible commitments because they raise the ex post costs of noncompliance above those that might be incurred in the absence of the treaty. They do this by (1) clarifying the commitment, (2) explicitly involving the home country's government, and (3) enhancing enforcement. ${ }^{31}$

BITs raise ex post costs of reneging on contracts by reducing the ambiguity of the host government's obligations. BITs are much more precise than customary international law in this area. They also provide a broader legal framework in which to interpret specific contractual obligations. Precision removes potential avenues of plausible deniability, making it clearer to a broader range of audiences (domestic audiences, other foreign investors, other governments), that an obligation has been disregarded. Clear violations imply a much greater reputational cost than do actions not clearly barred by law. ${ }^{32}$

The second way BITs raise ex post costs of reneging is by involving the investor's government as a treaty party. BITs are negotiated between sovereign states. Stateto-state legal arrangements implicate the interests of the home government more directly than do simple investment contracts between private parties and host governments. The home government has an interest in broader principles of goodfaith treaty observance. Treatment that violates a BIT qualifies as a breach of the fundamental principle of international law: pacta sunt servanda (treaties are to be

30. There is debate in the literature about the impact of BITs on investment flows. The small number of papers on the subject have generated inconsistent results. The most recent and sophisticated study of which we are aware, however, concludes that BITs do, indeed increase FDI and serve as a substitute for good domestic institutional quality; see Neumayer and Spess 2005. Other relevant studies include Hallward-Driemeier 2003; Tobin and Rose-Ackerman 2003; and UNCTAD 1998.

31. We cast our argument in the credible commitments framework, but our competition argument may be compatible with signaling theories as well. Some of the empirical implications would be different than those we describe here, however. If a BIT is a signaling device, we would expect more reliable rather than less reliable property rights protectors to sign them. We might also expect less reliable governments to sign one treaty, rather than multiple treaties, since one should suffice to send the signal. Empirically, we tend to observe multiple signings per host, which leads us to frame the issue as one of credible commitments rather than costly signals that reveal type. Both frameworks could, however, explain a competitive dynamic to sign BITs.

32. See Abbott et al. 2000; Lipson 1991; and Guzman 2002. 
observed). Reneging on a contract governed by a treaty arrangement can damage important foreign policy interests.

Finally, BITs raise ex post costs by significantly enhancing contract enforcement. These agreements contain mandatory dispute settlement provisions that investors are entitled to use when they feel the host state has violated the relevant BIT. Significantly, investors can begin arbitration proceedings without the approval or support of their home government. Moreover, the host can neither prevent the legal proceeding from going forward, nor control the final decision of the international arbitration tribunal. The international tribunal can require a host found to be in violation of its obligations to pay monetary damages. The sovereign host state could, of course, refuse to pay, but that decision could have even more profound reputational consequences: when a government spurns the decision of a neutral authoritative third party with which it has voluntarily precommitted to comply, a range of important actors_- public and private-are likely to infer that that government is an unreliable economic partner. By giving private parties a right to pursue and receive a legal remedy, BITs boost the credibility of the host government's commitment. As a result, we would expect some violations to be deterred by a BIT commitment and expected returns to investments to increase accordingly.

Do these formal dispute settlement mechanisms actually come into play in the way we have described? Theoretically, we should expect such arbitrations to be rare, because fully informed parties should be able to settle "out of court" and avoid litigation costs. When we do observe arbitration, it would be more likely to indicate information asymmetries than the seriousness of the case. ${ }^{33}$ Nonetheless, a significant number of cases have in fact gone to arbitration. A recent conservative estimate puts the number at at least 160 cases. ${ }^{34}$ Due largely to controversial measures taken by its government in early 2002, Argentina alone has recently been a party to some thirty BIT arbitrations, most of them under ICSID and the rest under UNCITRAL rules. ${ }^{35}$ BIT arbitrations have given rise to a number of significant awards, including recent decisions against the governments of the Czech Republic (\$350 million), Lebanon (\$266 million), and Ecuador (\$70 million). ${ }^{36}$

In short, BITs represent a credible commitment because of the range of ex post costs-diplomatic costs, sovereignty costs, arbitration costs, and reputational costs-involved in both their observance and their violation. We argue below that some governments have incentives to increase these costs in order to attract FDI.

33. This point has long been recognized in the law and economics literature, see Bebchuk 1984.

34. UNCTAD 2004. This number omits, of course, disputes that were resolved prior to the arbitration stage.

35. See 〈http://www.bomchilgroup.org/argmar04.html\#16〉. Accessed 20 June 2006.

36. For examples of awards, see reports of the International Institute for Sustainable Development, available at 〈www.iisd.org/investment $\rangle$. Accessed 20 June 2006. See also The National Law Journal, Arbitration Survey, "Global Litigation," 15 September 2003. See also 〈http://blog.lewrockwell.com/ lewrw/archives/Friedman-BITs-9-15-03.pdf $\rangle$. Accessed 20 June 2006. 


\section{Competitive BIT Signings: Logic and Implications}

In the previous section we argued that BITs allow governments to credibly commit themselves to protect investors' property rights. The ability to do so lowers risks and increases expected returns to investment. If this is the case, BITs can be a mechanism-such as favorable tax treatment, lower wages, and efficient infrastructure-for making a jurisdiction a more attractive place in which to invest. As with these other mechanisms, committing to a BIT involves costs for the host government. We characterize these as "sovereignty costs." They are the costs any government pays when it negotiates, ratifies, and complies with an investment treaty. We would include here the political costs of assembling a coalition in support of foreign investors' rights, as well as the costs associated with giving up a broad range of policy instruments relevant to domestic social or developmental purposes (taxation, regulation, performance requirements, property seizure, and currency and capital restrictions). Most striking are the sovereignty costs associated with the delegation of adjudicative authority: virtually any legal change or rule that affects foreign investors is potentially subject to review by a foreign tribunal. The decision to sign a BIT always involves an assessment by the host of whether the expected benefit of attracting an additional increment of foreign capital outweighs these costs. In many cases, the answer is no. In this section, we discuss the conditions under which the expected benefits for a particular government might outweigh these sovereignty costs.

BITs can attract capital from two broad resource pools. First, they can shift resources from consumption or domestic investment, effectively stimulating new international capital investments that would not have been made absent the treaty. Second, and more importantly for our theory, BITs can redirect international capital flows from one venue to another. A BIT gives the host signatory a "reputational advantage" over otherwise comparable rivals in the competition for (re)distribution of an existing investment pool. ${ }^{37}$ The possibility of investment diversion means that governments may have competitive reasons to implement BITs. It is the ability of a BIT—or at a minimum, its perceived ability—to give one country an advantage over other similarly situated countries in the competition for capital that we hypothesize as provoking many BIT signings. ${ }^{38}$

The strategic structure we are describing creates serious collective-action problems among potential host countries. Collectively, they might be better off resisting the demands of investors (avoiding the sovereignty costs described above), but individually it is rational to sign in hopes of stimulating capital inflows. In recognition of this dynamic, one finds cases of regional attempts to coordinate host resistance. In the Caribbean, for example, collective efforts have been made

37. This redistributive effect contrasts with customary international law, under which all potential hosts have the same obligations and enjoy the same benefits.

38. Guzman 1998 provides a more complete discussion of the potential impact of competition on BITs. 
to reduce BIT concessions, ${ }^{39}$ though predictably the "cartel" has been difficult to maintain. ${ }^{40}$ The breakdown of such efforts is consistent with the competitive context we believe accounts for the proliferation of BITs over the past several years.

A competitive theory of BITs has at least four observable implications. First, BITs should diffuse among host country competitors-countries that, from an investor's point of view, are closely substitutable venues for investment. It is precisely these countries that should display the clearest evidence of interdependent decision making. This is a unique prediction of competitive theory. No other diffusion mechanism - whether hegemonic, cognitive, or ideational-makes this specific prediction.

Second, BITs should spread most readily to countries where the competition for capital is the most intense. Competition intensifies where the number of plausible hosts for a particular investment project is greatest. For this reason, host competition for investment in extractive goods is far less intense than in light manufactures: while the number of countries in which bauxite mining is profitable is quite limited, almost any jurisdiction can host a Nike plant. If our competition hypothesis is correct, these treaties should be more prevalent where host competition is most fierce: in light manufactures rather than in primary production or extractive industries. This prediction is the exact opposite of what one might expect were BITs propelled in a "hegemonic" fashion, by the home country. From a home government's point of view, theories of obsolescing bargaining should predict the need for enforceable investment protections precisely in those industries that involve large upfront difficult-to-relocate investments. Obsolescing bargaining ${ }^{41}$ suggests that investors are more likely to demand treaties to protect their extractive and primary production investments, at least relative to easier-to-relocate light manufactures. $^{42}$

Third, BITs should spread as the pool of available capital grows. As the pool of global capital grows, any competitive advantage (such as that conferred by a BIT) should yield a larger marginal increase in FDI inflows. Thus, the expected return per BIT should increase with the size of the investment pool, which encourages

39. CARICOM countries, for example, produced a document entitled "Guidelines for Use in the Negotiation of Bilateral Treaties" that states, among other things, that CARICOM countries should not accept any restriction on the use of performance obligations and that they should retain the right to nationalize and to "determine at the time of nationalization the quantum of compensation and the terms of payment." Caribbean Community Secretariat, reproduced in "UNCTAD, International Investment Instruments: A Compendium," Vol. III.

40. Jamaica, a member of CARICOM when the guidelines were adopted, signed a string of BITs with important partners in the late 1980s and early 1990s, including the United Kingdom (1987); Switzerland (1990); the Netherlands (1991); Germany (1992); France (1993); Italy (1993); the United States (1994); Argentina (1994); and China (1994). These BITs include performance requirements and compensation provisions that are inconsistent with the CARICOM guidelines.

41. See Vernon 1971; and Vernon 1977.

42. Kobrin 1987 finds that manufacturing is not characterized by the inherent, structurally based and secular obsolescence that is found in the natural resource-based industries. 
hosts to scramble to improve access to a share of the bigger "pie." While other researchers have suggested that BITs may contribute to a growth in FDI, ${ }^{43}$ our theory suggests a possible feedback loop: the expectation of greater payoffs may stimulate more treaties. This relationship is not predicted by more sociological explanations, which might expect BITs to proliferate as a function of the density of BITs themselves, rather than the growing volume of investment. Nor is it predicted by learning theories, which would presumably require a demonstration that BITs actually "work" in attracting capital.

Finally, while all countries should be subject to some degree to the competitive pressures we have theorized above, BITs should diffuse somewhat more readily among host governments that lack credibility. For these countries, a BIT can be expected to make a real difference to investors, other factors held constant. In countries that already have institutions and practices that are favorable to investors, transparent, and predictable, a costly BIT adds relatively little value. These states may be able to compete for capital on the basis of their "inherent" credibility. This relationship is in principle consistent with power-based explanations (powerful home governments may be more likely to demand BITs from unreliable hosts than inherently reliable ones), but it is much less consistent with more sociological accounts discussed in Simmons, Dobbin and Garrett in this issue. If governments have been "socialized" to accept the dominant paradigm for investor protection, there would be no reason for the more credible host governments to largely exempt themselves.

A competitive theory of BITs predicts that the host countries most likely to sign treaties will be those whose competitors have signed, those who depend on manufacturing over extractive production, and those with a credibility gap. More generally, a competitive theory predicts increased treaties as the pool of available capital grows. In the following section, we develop an empirical strategy for testing these hypotheses against alternative explanations.

\section{Empirical Methods and Data}

\section{Analytical Design}

We use an event history framework to estimate the duration of time before two countries sign a BIT. Our analysis begins in 1958, the year before the first BIT, and includes those BITs concluded up to 1 January 2000, the last year for which we have accurate data. Since the focus of the analysis is a bilateral agreement between governments in a given year, the appropriate unit of analysis is the country dyad-year. In each dyad, we identify the potential "home" and the potential "host" country based on their relative level of development, as measured by GDP per capita. Of course, such designations become less meaningful the closer the 
members of the dyad are in their level of development. But treaties among countries of a similar level of development—especially at the higher end-are considerably less likely. In the reported analyses we exclude "developed dyads" from the sample in order to minimize the bias from estimates derived from "irrelevant dyads." ${ }^{44}$ Otherwise our sample includes all independent states, as identified by Gleditsch and Ward. ${ }^{45}$

Event history methods offer a convenient way to incorporate time dependence in models of policy or innovation adoption. Our formulation is slightly more complicated than most since the unit of analysis is the country dyad and the model includes variables measured for one or the other member of the dyad as well as for the dyad itself. We estimate the following equation:

$$
y_{i j, t}=\alpha X_{i, t}+\beta Z_{j, t}+\delta V_{i j, t}+\rho W y_{t-1}^{*}+\varepsilon_{i j}
$$

where $y_{i j}$ is the number of years without a BIT between countries $i$ (host) and $j$ (home), $X$ is a vector of conditions that affect country $i$ 's calculations, $Z$ is a vector of conditions that affect country $j$ 's calculations, $V$ is a vector of characteristics of the relationship between countries $i$ and $j$, and $W y^{*}$ is a vector of spatial lag terms in which a count of BITs among other host countries in the previous year $\left(y^{*}\right)$ is weighted by various measures of their distance $(W)$ to country $i$ (see our discussion of spatial lags below). We estimate this equation with a Cox proportional hazard model, a useful estimator when one does not have strong assumptions about the effect of time on the baseline hazard.

\section{Data and Measures}

Our dependent variable is the number of years a dyad goes without a treaty, marked by the year of a treaty's signing, rather than the year in which it enters into force. ${ }^{46}$ We reason that the signing not only approximates the moment during which a government deliberates over the treaty but is also the more important event for

44. We exclude dyads in which both members are classified as "high income countries" by the World Bank [that is, dyads in which both members have a GDP per capita of over \$6,000 (in 1987 \$US) in a given year], thus excluding 125 BITs in the analysis.

45. Gleditsch and Ward 1999. Restricting our sample to those states (and their dates of existence) identified by Gleditsch and Ward means that we exclude eighteen BITs listed in the UNCTAD data, such as the fourteen to which Hong Kong was party as well as those involving states such as the United Arab Emirates and Slovenia, which occur several years prior to the dates that Gleditsch and Ward list the states as independent. The relatively inclusive sample ensures that we will encounter missing data, particularly for smaller countries. We experiment with several methods of managing missing data, none of which alter the substantive findings. For the results below, we have estimated missing values of time-varying covariates with decade means where possible and appropriate. Such extrapolations buy a more inclusive sample at the expense of potentially underestimated standard errors; see King et al. 2001.

46. While approximately forty dyads have entered into second and, in one case, third treaties, we predict the duration until the first treaty. 
purposes of sending a proinvestment signal to international markets. ${ }^{47}$ Both UNCTAD and the World Bank's ICSID track the date and signatories of BITs. While the two sources basically agree, UNCTAD's list is more recent and more comprehensive ${ }^{48}$ As the equation above indicates, our independent variables take on one of four analytic forms: (1) independent factors associated with the "home" country; (2) independent factors associated with the "host" country; (3) factors associated with the relationship between host and home countries; and (4) spatial lags of the dependent variable.

\section{Spatial lags of the dependent variable: Competition and cultural emula-} tion. To assess the source and strength of the various influences of policy diffusion we construct a series of spatial lags, modeled largely after those in Simmons and Elkins. ${ }^{49}$ Spatial lag models treat spatial dependence in the same way time-series models treat serial correlation..$^{50}$ Instead of (or, in our case, in addition to) lagging the value of the dependent variable one unit in time, one "lags" it one (or more) units in space to capture the behavior of neighbors. Thus, the general formulation of the spatial lag above, $W y^{*}$, in which $W$ is an $\mathrm{N}$ by $\mathrm{N}$ by T spatial weights matrix that maps the distances between units for each year and $y^{*}$ is an $\mathrm{N}$ by $\mathrm{T}$ matrix of values that represent some function of the dependent variable for all countries other than $i$. In our case, $y^{*}$ represents the sum total of BITs in force for each host country in a given year. ${ }^{51}$ We then compute the weighted average of $y^{*}$ by dividing the sum of its product with $W$, by a row sum of $W$. Thus, the spatial lag for country $i$ using the weight $w$ is as follows,

$$
=\frac{w_{i j} y_{j}^{*}+w_{i k} y_{k}^{*}+\cdots+w_{i n} y_{n}^{*}}{w_{i j}+w_{i k}+\cdots+w_{i n}}
$$

This computation of $W y^{*}$ allows an intuitive interpretation of the spatial lag: it is the average number of BITs in force among other host countries, weighted by some distance to country $i$. Since the spatial lag is endogenous, we lag it one year

47. "As the great majority of BITs are ratified, it is reasonable to assume that, in the perception of investors, signing a BIT is the crucial action: Once a BIT is signed, or expected to be signed, the market has absorbed it or begins to absorb it"; UNCTAD 1998, 106.

48. Our comparison of the two data sets found that, for the years they overlapped (1959-97), UNCTAD included over two hundred treaties not included in the ICSID database.

49. Simmons and Elkins 2004.

50. Anselin 1988 .

51. This formulation assumes that it is the accumulation of treaties among peers, not the "event" of their recent signing, that provokes a response. We also experimented with an event trigger by calculating the number of BITs signed by others in the previous year. In fact, the results were largely comparable. 
to capture the behavior of other host countries in the previous year, a chronology that makes more sense for the causal logic of diffusion as well. ${ }^{52}$ Note that the $W$ matrix can represent not only geographic distances, but also economic, cultural, or political distances among countries. ${ }^{53}$

Our theory predicts interdependent decision making among host countries that compete for the same sources of global capital. Thus we need to determine the "competitive distance" between hosts. We create spatial weights that capture this distance in three ways. The first measures the degree to which host governments compete in the same foreign markets; that is, whether they have the same export trade relationships. ${ }^{54}$ (All data sources and descriptive statistics are provided in the Data Appendix.) This is a useful indicator because trade competitors are also likely to be competitors for FDI and empirical studies show that the two are strongly correlated. We reason that countries that compete for export markets are structurally positioned to compete for the same sources of FDI as well. The second measure records the degree to which nations export the same basket of goods. ${ }^{55}$ This measure captures the idea that investors choose between alternative locations for direct investment that they consider close substitutes with respect to the countries' traditional export products. For example, an automobile manufacturer might consider investing in countries that produce steel but will be unlikely to consider those whose leading export is cocoa. Our third measure captures the degree to which countries have similar educational and infrastructural resources. Assuming that potential foreign direct investors are concerned with a country's human assets as well as its technological and communications infrastructure, we reason that countries with similar educational and infrastructural profiles will compete for the same

52. While spatial lags are common solutions to estimating the relational effects that we hypothesize, they do introduce a potential degree of endogeneity. Unless nondiffusion predictors are included in the model, spatial lags can absorb these effects when the domestic variables are correlated within the network. For this reason, some scholars have moved towards simultaneous equation modeling, in order to model the endogeneity. Recent Monte Carlo evidence reported in Franzese and Hays 2004 suggests that the costs associated with such models may outweigh their benefits in large samples. Our solution is to specify the nondiffusion components as completely as possible and to lag the spatial lag one year. Nonetheless, we recognize that effects from spatial lags may be slightly inflated.

53. See Elkins and Simmons 2005; and Beck, Gleditsch, and Beardsley 2006.

54. We use the IMF Direction of Trade data to produce an $\mathrm{N}$ by $\mathrm{N}$ by $\mathrm{T}$ matrix of correlations (between countries) across the countries' proportion of exports to each of the 182 partner countries. Two countries that export goods in the same proportions to 182 countries will have a score of 1; while those with entirely opposite relationships will have score of -1 . For a similar approach, see Finger and Kreinin 1979. Network analysts often use this sort of measure to identify competitors; see Wasserman and Faust 1994.

55. We calculate the distance between countries according to their export products, using information from the World Bank's World Development Indicators (WDI) that describes a country's export mix. These indicators tap the value of exports (in 1995 \$US) in sectors such as food, fuel, agricultural raw materials, ores and metals, and arms. We calculate the correlation between countries for each year across thirteen such indicators. The result is a measure, ranging from -1 to 1 , of the similarity between countries according to the products they export. 
pool of capital. ${ }^{56}$ For all three competition measures, we compute a spatial lag by anchoring the distances (measured as correlations) at zero by adding 1 to each score and then using these distances to calculate a weighted sum of BITs in force in all other host countries in the previous year.

The competition distances themselves appear to have a fair degree of validity. For example, Figure 6 plots the values for the "distance" in export products between Brazil and select countries across time. If these values are to be believed, Brazil's products correlated quite highly with those of most Latin American countries in the 1960s and 1970s. This correlation decreased in the 1990s, at which time Brazil's export profile began to resemble that of the United States and Canada more than that of its Latin American neighbors. This finding is consistent with the common interpretation of the increasingly diversified Brazilian economy, whose exports in everything from technology to agriculture now compete directly with the United States and less directly with smaller Latin American states. ${ }^{57}$

We also use spatial lags in a similar way to measure the influence of an important alternative explanation suggested in Simmons, Dobbin, and Garrett ${ }^{58}$ - that of cultural peers. We use three measures of "cultural distance": predominant religion, colonial heritage, and predominant language. The spatial lag for these "distances" is calculated in the same weighted-average manner as for the competitive distances. Unlike the competition measures, the cultural distances are binary; a country either shares a common language with another, or it does not. The cultural spatial lags, therefore, are equivalent to the mean number of BITs in force among those host countries with the same cultural identity (religion, language, or colonial heritage). These measures capture an important possibility: that BITs result more from socially constructed emulation of policies of important reference groups than from hard-nosed economic competition. Note that this measure does not capture whether BITs are more likely between cultural peers, an effect we test with the cultural distance variables themselves (see below).

Alternative diffusion mechanisms: Learning and coercion. Finally, we seek to capture the effects of policy learning and coercion. Our notion of learning, consistent with that articulated in Simmons, Dobbin, and Garrett, ${ }^{59}$ implies that policymakers from host countries are motivated to sign BITs based on the treaties' demonstrated benefits (specifically, increased FDI). Our model does not assume that policymakers have Herculean powers of observation or analysis; nor does it treat them as remedial statisticians. We assume simply that policymakers assess the success of countries in attracting investment over recent years given the coun-

56. We compare such investment profiles by calculating correlations, by year, between countries across roughly fifteen educational and infrastructural variables selected from the WDI. These distances range from -1 to 1 .

57. Baer 2001.

58. Simmons, Dobbin, and Garrett, this volume.

59. Ibid. 

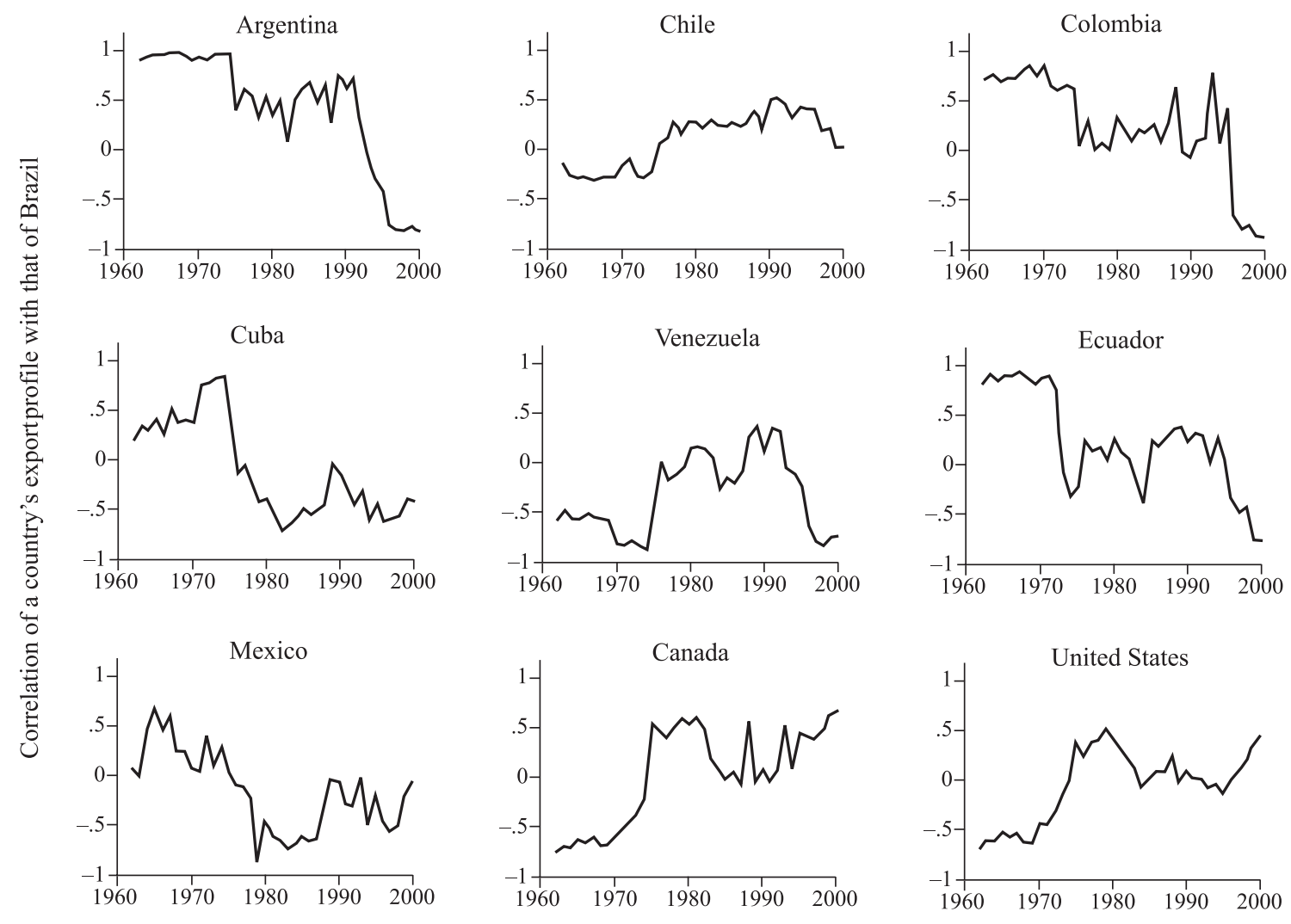

Year

FIGURE 6. A measure of export market similarity: The Brazilian case 
tries' level of development and their number of treaties in force during this time. We replicate this cognitive process by regressing, each year, the average FDI inflows as a percentage of GDP for the previous five years on the average number of treaties in force for that country during that period as well as its average GDP per capita. The standardized regression coefficient for the BITs variable in each of these yearly equations is our indicator of a policymaker's estimate of the payoff of these treaties in terms of increased investment. ${ }^{60}$ Thus, we assume that each year decision makers observe and draw conclusions about the effects of BITs on investment, controlling for a country's level of development, and that all actors observe the same signal.

Because FDI data is sparse in the 1960s, the effect of the treaties is incalculable with any degree of certainty, both for us and for policymakers at the time. Throughout the 1970s and most of the 1980s, the apparent effect of BITs is effectively zero or even negative. However, by the early 1990s - the period in which more than half of existing BITs were signed-BITs appear to have obvious payoffs. Those countries with BITs in force in those years are clearly also the recipients of investment. ${ }^{61}$ The coefficient in 1990, for example, suggests that each BIT in force is associated with an extra .05 percent of GDP in investment. Thus, a country with 50 BITs (for example, Chile) has almost 2.5 percent of its GDP (that is, for Chile, more than $\$ 1$ billion) in investment more than a country without a BIT. This is the difference between having no FDI and having the worldwide average for a lowor middle-income country, for which gross FDI averages around 2.3 percent of GDP. To an observant host country in 1990, BITs would certainly appear to have some demonstrable benefits.

We consider one final interdependent mechanism, coercion. It may be that potential hosts are coerced or at least strongly encouraged to enter into BITs. If so, a likely juncture for the application of such pressure is at the time a country seeks International Monetary Fund (IMF) credits. We incorporate a dichotomous measure of whether or not a country has drawn on IMF resources in a given year. Though we do not believe the pursuit of or entry into BITs is explicitly stipulated in formal loan conditions, there may be more subtle pressures on a state in balanceof-payments difficulties to use these treaties to attract foreign capital.

Home country considerations. The proliferation of BITs could be explained by two home country considerations: the desire to protect existing overseas capital, and the desire for additional investments. These considerations could significantly influence the pool of BITs that is potentially available, independently of

60. In order to compute these results, we use only those data that are immediately available to us (and, more to the point, to policymakers). We reason that our informational constraints should match those of policymakers. As such, we use data reported in the World Bank's WDI and do not make efforts to impute or otherwise fill in missing data in these equations.

61. Such mixed results do not seem surprising given the discrepant findings of scholars on this question (see fn. 30). 
any competitive dynamic among potential hosts. In the analysis that follows, we control for the total FDI "exposure" of the home country; that is, the degree to which a country's capital is actually invested abroad. For this we use a measure of net FDI outflows as a proportion of GDP (scored positively when outflows outweigh inflows and negatively when inflows outweigh outflows). On average, we expect high outflows to produce a greater willingness to supply BITs on the part of investors' governments.

In models not reported here, we also include country dummies for the identity of home governments with the most active BIT programs (Germany, Switzerland, France, United Kingdom, Italy, and the United States) in order to absorb any idiosyncratic tendencies to pursue BITs and to capture the effect of large BIT programs.

Host country considerations. Our competitive story of the proliferation of BITs suggests that competitive reputation building, through BITs, can set off a sequence of treaty signings among countries that compete with one another. Although all countries may be subject to such competitive pressures to some degree, we expect governments with greater indigenous credibility to be less willing to pay the sovereignty and other political costs associated with concluding BITs. We capture this idea by using an indicator of investors' perceptions of corruption in the host country. The more corrupt a state is perceived to be, the more necessary it becomes to lure investors with an explicit promise to delegate adjudication to an authoritative third party. We complement this measure with one of the nature of the legal system itself. Some research suggests that common law systems tend to provide better property rights protections; ${ }^{62}$ civil law systems are more likely, these scholars argue, to implement regulatory solutions to perceived social conflict ${ }^{63}$ - arguably, the kind of approach likely to make external capital flinch. If civil law systems are less oriented toward credible rules of capital protection, governments in those systems should more frequently reach for an external commitment mechanism, such as a BIT. ${ }^{64}$ Finally, we would like to use a measure of the extent to which the host's legal system is perceived by foreign investors as strong and impartial. Unfortunately, the measure that appears to be most appropriate for tapping legal strength and impartiality ("law and order") is confounded by the inclusion of investors' assessment of popular observance of the law, which likely has little to do with the judiciary's attitude toward foreign investors. Nonetheless, our argument implies that a reputation for "law and order" should reduce a host's need to sign a BIT.

Another important factor, and one with implications for our competition story, has to do with a country's exposure to competition. If BITs are driven by compe-

62. La Porta et al. 1997 and 1998.

63. Botero et al. 2002.

64. We use an indicator of a English Common law tradition generated by the World Bank and used by La Porta et al; see Easterly and Sewadeh 2001. We have some misgivings about using this measure to capture reputation for property rights protections, especially since Simmons (forthcoming) has shown that common law countries are much less likely to sign human rights treaties, which points to a more general orientation toward international treaties of all kinds. 
tition for capital, they should be most prevalent where that competition is most fierce. We have argued that competition for capital is most cutthroat in manufacturing; by comparison, there are limited sites worldwide that produce copper or other extractive commodities. The fewer the alternative investment sites, the more protected the host is from international competition, and the less likely a host is to sign a BIT. To capture this idea, we construct a measure of extractive industry dependence by summing the share of each country's exports of both fuel and "ores and metals," as recorded in the World Bank's World Development Indicators (WDI). Approaches emphasizing the coercive role of dominant powers would anticipate a positive coefficient for extractive industries, since these are most subject to obsolescing bargaining and hence intensified political risks. Our expectation, however, is that this effect will be swamped by competition among hosts for manufacturing FDI, and we anticipate a negative effect. The outcome on the extractive industry variable thus provides a fairly crisp test of the importance of competition among hosts in explaining the proliferation of BITs.

Quite aside from indicators of the need for a credible commitment discussed above, a number of economic conditions make particular hosts especially attractive BIT partners. We control for the economic desirability of the investment site by controlling for market size of the host country (log of the host's GDP) ${ }^{65}$ the host's level of development (GDP per capita), ${ }^{66}$ the quality of the host's workforce (rate of illiteracy), and the host's growth (GDP growth rate). ${ }^{67} \mathrm{We}$ also include a rather direct measure of the host's attractiveness for capital: FDI net inflows in the previous year, as a percentage of GDP. ${ }^{68}$

Finally, we control for other political and policy conditions in the host country. Since investors may see democracies as less capricious, we control for the host's level of democracy. It is possible that the pattern of BITs is driven by a few countries' aggressive privatization programs, and so we control for the value of privatized assets in a given year. Finally, we recognize that to sign BITs requires a certain degree of diplomatic capacity. We account for the diplomatic and legal capacity to enter into BITs by controlling for the total number of embassies a country hosts and has established in foreign countries. ${ }^{69}$ A host with extensive diplomatic representation is more likely to have the international political and legal capacity to conclude a larger volume of treaties.

Characteristics of country pairs. In this analytic category we identify the relational variables that might be associated with the likelihood of an agreement

65. See Kobrin 1976; and Wheeler and Mody 1992.

66. Henisz 2000.

67. See Kobrin 1976; and Wheeler and Mody 1992.

68. The literature on agglomeration economies, stressing the increasing benefits of colocation by economic units, provides a justification for including prior FDI inflows; see Wheeler and Mody 1992. As current and future FDI is likely affected by the very agreements we predict in this model, we lag the measure one year.

69. See Guzman and Simmons 2005. 
between the two nations. We focus on three kinds of relationships: business, security, and cultural relationships. Since firms are likely to want to invest in or near their export markets and to otherwise take advantage of vertical downstream linkages ${ }^{70}$ we control for the intensity of business transactions, proxied by the extent of trade between the two countries. Investment agreements may also have a foreign policy ${ }^{71}$ or even a security rationale as well. To address this possibility, we include a measure of the intensity of the alliance relationship for each pair. We also consider the possibility that BITs reflect cultural relationships, although this variable could have opposing effects. On the one hand, it may be easier for states with cultural similarities to negotiate successfully. On the other hand, if cultural similarities also reduce the perceived risks of investment, a common culture might operate in the opposite direction, reducing the need for a BIT. We test the relationship between cultural characteristics and BIT signing by coding country pairs with shared language and colonial traditions. Note that these variables should not be confused with the cultural spatial lags, which are measures of a host's peers' treaty activity.

\section{Findings}

We present estimates (as hazard ratios) from three specifications of our model (Table 2). A hazard ratio of more than 1 represents a positive effect on the odds of a BIT; less than 1, a negative effect. The first regression includes the export partner lag together with the full set of covariates described above. The last two regressions include one of the remaining two competitive spatial lags (export product similarity and infrastructure/workforce similarity) in a reduced form of the model. Several clear empirical patterns begin to emerge. There is fairly consistent and convincing evidence of the importance of competition for capital among developing countries in explaining the proliferation of BITs over the past four decades. In all cases, higher rates of BIT signing among competitors (however measured) appear to have increased the rate at which a given country itself enters into a BIT at statistically significant levels. One can appreciate the size of these effects in Figure $7 \mathrm{a}$, which plots the survival curve for two different values of the spatial lag calculated from the "export product similarity" measure, the competition variable with the largest impact. In this illustration, a country whose competitors average

70. The literature that has focused on firm and industry level explanations for the location of FDI emphasizes that firms that depend on foreign sales are more likely to invest overseas. For example, some research suggests that a firm's decision to deepen its presence in a particular country is influenced by the extent of its prior experience in that jurisdiction; see Ball and Tschoegl 1982. Others have found that firms are more likely to invest where they have strategic advantages, and these are plausibly connected with vertical downstream linkages; see Kimura 1989. The measure proposed here assumed these effects may show up in the aggregate trade relationships at the national level.

71. See Gowa 1994; and Pollins 1989. 
TABLE 2. A model of BIT signings: Cox proportional hazard model

\begin{tabular}{|c|c|c|c|}
\hline Explanatory variables & Model 1 & Model 2 & Model 3 \\
\hline \multicolumn{4}{|l|}{ Competitive theory } \\
\hline BITS AMONG EXPORT MARKET COMPETITORS & $\begin{array}{l}1.05^{* * * *} \\
(0.01)\end{array}$ & & \\
\hline BITS AMONG EXPORT PRODUCT COMPETITORS & & $\begin{array}{l}1.11 * * * \\
(0.04)\end{array}$ & \\
\hline BITS AMONG INFRASTRUCTURE COMPETITORS & & & $\begin{array}{l}1.04 \\
(0.02) * *\end{array}$ \\
\hline AVERAGE ANNUAL GLOBAL FDI FLOWS & $\begin{array}{l}1.32 * * * \\
(0.12)\end{array}$ & $\begin{array}{l}1.53 * * * \\
(0.14)\end{array}$ & $\begin{array}{l}1.46^{* * * *} \\
(0.13)\end{array}$ \\
\hline HOST EXTRACTIVE INDUSTRIES/EXPORTS & $\begin{array}{l}0.73^{* *} \\
(0.09)\end{array}$ & $\begin{array}{l}0.73 * * \\
(0.09)\end{array}$ & $\begin{array}{l}0.72 * * * \\
(0.09)\end{array}$ \\
\hline PERCEPTIONS OF HOST CORRUPTION & $\begin{array}{c}1.03 \\
(0.04)\end{array}$ & $\begin{array}{c}1.01 \\
(0.04)\end{array}$ & $\begin{array}{c}1.01 \\
(0.04)\end{array}$ \\
\hline HOST LEGAL TRADITION (COMMON LAW) & $\begin{array}{l}0.66^{* * * *} \\
(0.05)\end{array}$ & $\begin{array}{l}0.65 * * * \\
(0.05)\end{array}$ & $\begin{array}{l}0.66^{* * * *} \\
(0.05)\end{array}$ \\
\hline \multicolumn{4}{|l|}{ Alternative diffusion explanations } \\
\hline BITS AMONG THOSE WITH SAME RELIGION & $\begin{array}{c}0.99 \\
(0.01)\end{array}$ & $\begin{array}{c}0.98 \\
(0.01)\end{array}$ & $\begin{array}{c}0.99 \\
(0.01)\end{array}$ \\
\hline BITS AMONG THOSE WITH SAME LANGUAGE & $\begin{array}{c}1.01 \\
(0.06)\end{array}$ & & \\
\hline BITS AMONG THOSE WITH SAME COLONIZER & $\begin{array}{c}0.99 \\
(0.04)\end{array}$ & & \\
\hline LEARNING FROM SUCCESS & $\begin{array}{l}1.85^{* * *} \\
(0.42)\end{array}$ & $\begin{array}{c}1.83 * \\
(0.61)\end{array}$ & $\begin{array}{c}2.13 * \\
(0.94)\end{array}$ \\
\hline COERCION: HOST USE OF IMF CREDITS & $\begin{array}{l}1.44^{* * *} * \\
(0.12)\end{array}$ & $\begin{array}{l}1.39 * * * \\
(0.11)\end{array}$ & $\begin{array}{l}1.43^{* * * *} \\
(0.12)\end{array}$ \\
\hline \multicolumn{4}{|l|}{ Host control variables } \\
\hline HOST GDP (LN) & $\begin{array}{c}1.07 * \\
(0.04)\end{array}$ & $\begin{array}{c}1.03 \\
(0.04)\end{array}$ & $\begin{array}{c}1.04 \\
(0.04)\end{array}$ \\
\hline HOST GDP/CAPITA & $\begin{array}{l}1.00 \\
(0.03)\end{array}$ & $\begin{array}{c}1.00 \\
(0.03)\end{array}$ & $\begin{array}{c}0.99 \\
(0.03)\end{array}$ \\
\hline HOST GDP GROWTH & $\begin{array}{l}0.97 * * * \\
(0.01)\end{array}$ & $\begin{array}{l}0.97 * * * \\
(0.01)\end{array}$ & $\begin{array}{l}0.97 * * * \\
(0.01)\end{array}$ \\
\hline HOST NET FDI INFLOWS ( $\%$ OF GDP), T-1 & $\begin{array}{c}1.01 \\
(0.01)\end{array}$ & $\begin{array}{c}1.01 \\
(0.01)\end{array}$ & $\begin{array}{c}1.01 \\
(0.01)\end{array}$ \\
\hline HOST ILLITERACY RATE & $\begin{array}{l}0.34 * * * \\
(0.06)\end{array}$ & $\begin{array}{l}0.30 * * * \\
(0.05)\end{array}$ & $\begin{array}{l}0.30 * * * \\
(0.06)\end{array}$ \\
\hline HOST CAPITAL ACCOUNT/GDP & $\begin{array}{c}1.01 \\
(0.01)\end{array}$ & $\begin{array}{l}1.01 * * \\
(0.01)\end{array}$ & $\begin{array}{l}1.01 * * \\
(0.01)\end{array}$ \\
\hline HOST LAW AND ORDER & $\begin{array}{l}1.34 * * * \\
(0.05)\end{array}$ & $\begin{array}{l}1.39 * * * \\
(0.05)\end{array}$ & $\begin{array}{l}1.38 * * * \\
(0.05)\end{array}$ \\
\hline HOST DEMOCRACY & $\begin{array}{c}0.99 \\
(0.01)\end{array}$ & $\begin{array}{c}0.99 \\
(0.01)\end{array}$ & $\begin{array}{c}0.99 \\
(0.01)\end{array}$ \\
\hline HOST DIPLOMATIC REPRESENTATION & $\begin{array}{l}1.01^{* * * *} \\
(0.00)\end{array}$ & $\begin{array}{l}1.01^{* * * *} \\
(0.00)\end{array}$ & $\begin{array}{l}1.01 * * * \\
(0.00)\end{array}$ \\
\hline HOST PRIVATIZATION RECORD & $\begin{array}{l}1.05^{* * * *} \\
(0.02)\end{array}$ & $\begin{array}{l}1.06^{* * * *} \\
(0.02)\end{array}$ & $\begin{array}{l}1.06 * * * \\
(0.02)\end{array}$ \\
\hline \multicolumn{4}{|l|}{ Home control variables } \\
\hline HOME NET FDI OUTFLOWS (\% OF GDP) & $\begin{array}{l}1.13^{* * * *} \\
(0.02)\end{array}$ & $\begin{array}{l}1.14^{* * * *} \\
(0.02)\end{array}$ & $\begin{array}{l}1.14 * * * \\
(0.02)\end{array}$ \\
\hline
\end{tabular}


TABLE 2. Continued

\begin{tabular}{|c|c|c|c|}
\hline Explanatory variables & Model 1 & Model 2 & Model 3 \\
\hline \multicolumn{4}{|l|}{ Dyadic control variables } \\
\hline DYADIC TRADE (\% OF HOST'S GDP) & $\begin{array}{c}1.59 * \\
(0.35)\end{array}$ & $\begin{array}{c}1.61 \\
(0.56)\end{array}$ & $\begin{array}{c}1.64 \\
(0.57)\end{array}$ \\
\hline COMMON COLONIAL HERITAGE & $\begin{array}{l}0.41^{* * *} \\
(0.09)\end{array}$ & $\begin{array}{l}0.40 \text { *** } \\
(0.09)\end{array}$ & $\begin{array}{l}0.41^{* * *} \\
(0.09)\end{array}$ \\
\hline COMMON LANGUAGE & $\begin{array}{l}1.57 * * * \\
(0.19)\end{array}$ & $\begin{array}{l}1.55^{* * * *} \\
(0.19)\end{array}$ & $\begin{array}{l}1.54 * * * \\
(0.19)\end{array}$ \\
\hline ALLIANCE & $\begin{array}{c}1.18 * \\
(0.10)\end{array}$ & $\begin{array}{c}1.20^{*} \\
(0.11)\end{array}$ & $\begin{array}{c}1.18 \\
(0.14)\end{array}$ \\
\hline \multicolumn{4}{|l|}{ Common "shocks" } \\
\hline COLD WAR & $\begin{array}{l}0.37 * * * \\
(0.08)\end{array}$ & $\begin{array}{l}0.31 * * * \\
(0.06)\end{array}$ & $\begin{array}{l}0.32 * * * \\
(0.06)\end{array}$ \\
\hline NUMBER OF BITS GLOBALLY, BY YEAR & $\begin{array}{c}1.03 \\
(0.03)\end{array}$ & $\begin{array}{c}1.00 \\
(0.03)\end{array}$ & $\begin{array}{c}1.01 \\
(0.03)\end{array}$ \\
\hline Observations & 206,766 & 208,610 & 201,073 \\
\hline Number of country pairs analyzed & 6,781 & 6,831 & 6,828 \\
\hline Number of BITs & 1,125 & 1,140 & 1,137 \\
\hline Log likelihood & -8723.114 & -8858.474 & -8823.590 \\
\hline
\end{tabular}

Notes: Standard errors are in parentheses.

*** Significant at $1 \%$; ** significant at $5 \%$; significant at $10 \%$.

fifteen agreements has a markedly increased risk of signing an agreement compared with a country whose competitors have refrained from signing. In the late 1990s (40 years after the inception of BITs), the difference between such countries in their probability of signing is almost 0.20 . The results of these three competition variables alone provide preliminary evidence that competition is central to the spread of BITs.

The evidence also suggests that as global FDI has increased, potential hosts have been more willing to sign BITs. One interpretation of this finding is that as the pool of FDI has increased, the competitive stakes for a share have grown. The pattern with respect to countries with predominantly extractive industries also provides corroboratory evidence for the competition theory. The results show that higher extractive production by the potential host reduces the propensity to negotiate a BIT (contrary to expectations based on investors' demands to address obsolescing bargains endemic to primary and extractive production). Figure $7 \mathrm{~b}$, which compares the signing rates for a government with a largely extractivebased economy versus one with an exclusively manufacturing-based economy, suggests that-ceteris paribus_-signing rates can differ by as much as 10 percentage points depending on a state's level of extractive material exports. Both the magnitude and stability of this effect across models suggests that it is a fairly robust finding.

We found inconsistent evidence, however, to support our expectation that host countries with a credibility gap are most likely to sign a BIT. Contrary to expec- 


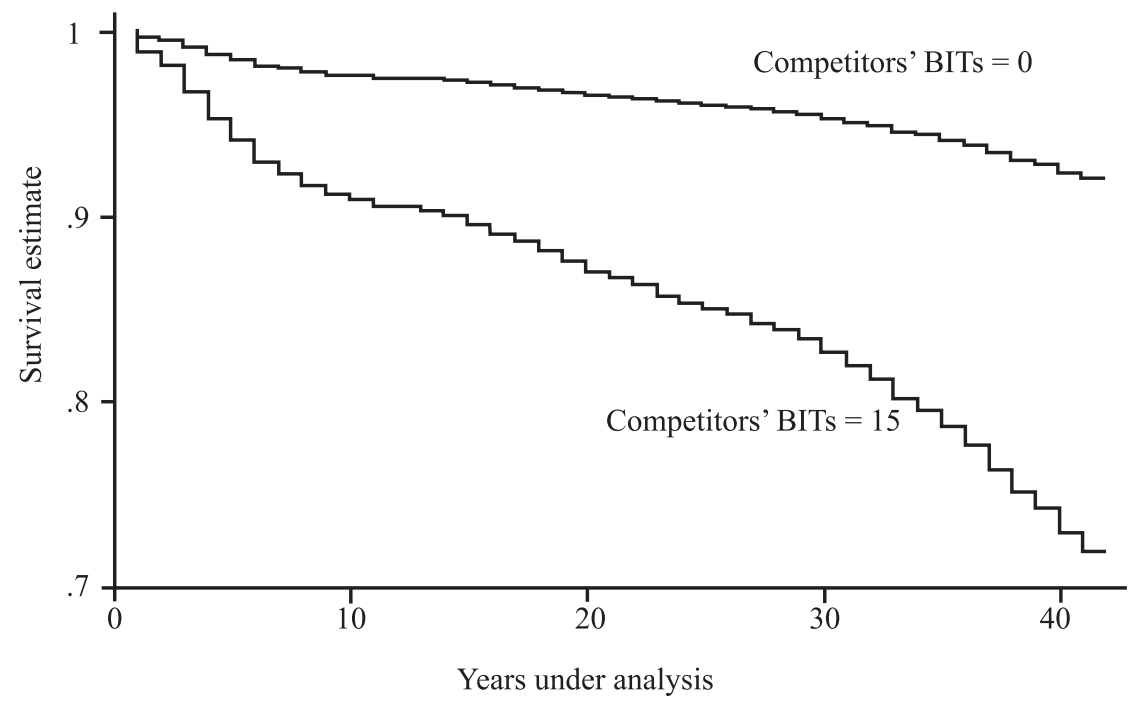

FIGURE 7a. Survival estimates according to the average number of BITs of host's competitors (measured by export product similarity)

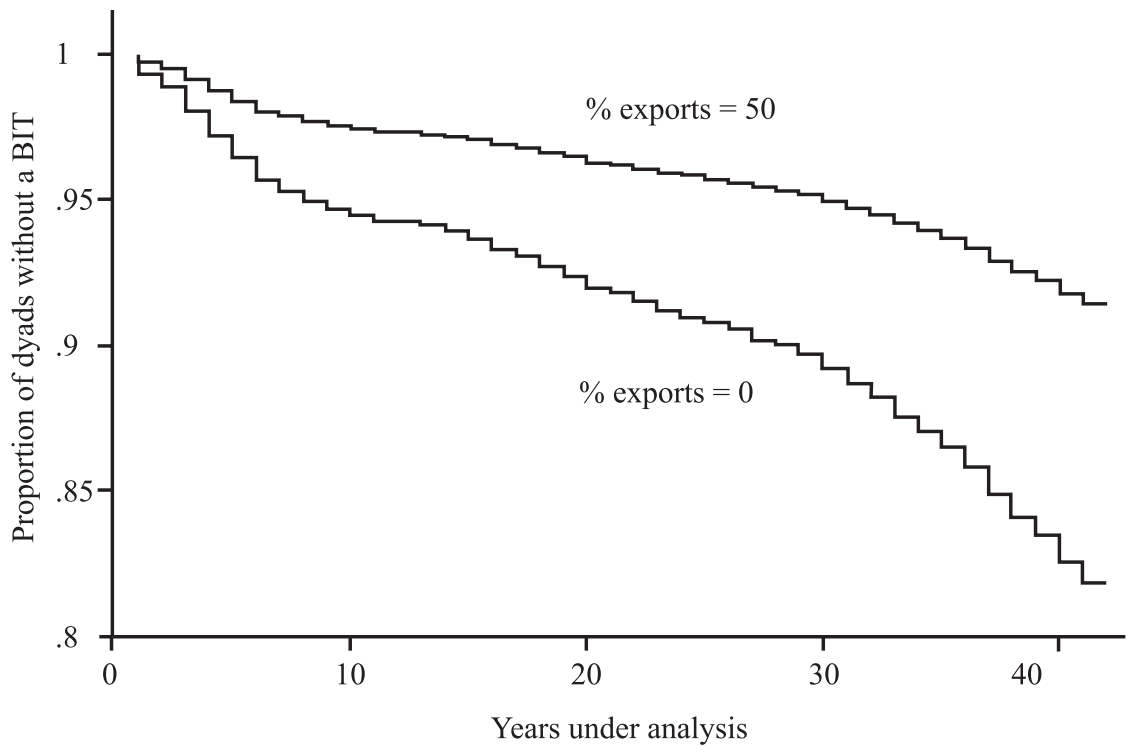

Note: Estimates derived from Model 2 in Table 2. BIT = bilateral investment treaty.

FIGURE 7b. Survival estimates according to host's percent of exports in extractive industries 
tation, BITs were more likely to be signed by countries with better reputations for "law and order." We have already noted that this indicator only partially reflects our argument, as it conflates perceptions of the strength of the court system with perceptions of popular willingness to obey the law. Even so, the strong positive result is surprising. One possibility is that this measure is picking up the relatively favorable orientation of some countries toward legal solutions to conflicts generally. As we expected, perceptions of corruption were in the correct direction, although the hazard ratio is not statistically significant in any specification that also contains "law and order." We should note that corruption is a significant determinant of signing a BIT whenever the LAW AND ORDER variable is not included. The common law variable did work as anticipated, but in light of the above findings, we think the prudent conclusion is that common law countries also refrain from entering into these agreements for reasons other than the reputational concerns developed here. ${ }^{72}$

In addition to the competition variables, our coercion variable (use of IMF credits) is significant in each of the models. This may mean that states seeking assistance from the IMF are encouraged to enter into BITs. Alternatively, it may be that the conditionality of IMF loans overlaps with the obligations of the BIT, reducing the costs of the latter. Interestingly, there is some evidence of learning from BIT outcomes. BITs are significantly more likely to be signed during years in which signatory states appear to be benefiting (in terms of FDI) from the treaties than when they are not. Such a pattern, of course, is consistent with our general theory of competition over shares of FDI. We found no evidence, however, that countries sign agreements in response to signings in their cultural networks. None of the spatial lags along religion, language, or colonial heritage had consequential effects.

Many of the variables that would predict home country interest in offering a BIT to a developing country had somewhat unpredictable, and muted, effects. The size of the host economy and previous FDI inflows (as a percentage of host GDP) showed effects in the predicted direction, although rarely statistically significant across the models we tested. Meanwhile GDP per capita and economic growth had, if anything, the opposite effects of what we would expect, although only the economic growth coefficients were significant. On the other hand, we did find evidence that countries with a high quality workforce, as measured by literacy rates, and with an export orientation (current accounts tending toward surplus), were more likely to sign BITs (illiteracy is associated with a reduced likelihood of a BIT). Our prediction that privatization programs in a host country would coincide with BIT agreements was borne out as well. Similarly, host countries with a larger diplomatic presence were also more likely to enter into BITs. Finally, host's degree of democracy had practically no effect.

Certain control variables describing the relationships between home and host countries were important predictors of BITs. While the direction of dyadic trade is

72. Simmons forthcoming. 
as hypothesized, the effect is statistically insignificant in two of the three models. Political and cultural relationships seem to be more important. In accordance with expectations, BITs are more likely among allies, which could suggest a somewhat coercive element to their conclusion. A common language within the dyad makes it much more likely that a pair of countries will negotiate a BIT, but a colonial link reduces by about two-thirds the likelihood that a country pair will do so. Perhaps investors in home countries perceive the risk in their colonial "families" to be lower than in other states. After all, colonies' legal institutions are likely to be similar to, if not partially overlap with, legal institutions in the mother country and fellow former colonies. This fits with our conception of BITs as being created to establish a credible legal framework for investment that is otherwise lacking.

In models not reported here, we attempted also to control for the BIT "programs" of particularly active countries by including country dummy variables for the five most active hosts and the five most active home countries. All were highly significant, with the partial exceptions of Germany and the United States. Their inclusion reduced substantially the effect of two variables, the volume of bilateral trade between country pairs and the home country net FDI. The robustness of the other results to the country dummies, however, reassures us that our results are not driven by idiosyncratic policies in a few of the most active countries.

Finally, we consider the potential impact of commonly experienced "shocks" on the propensity to sign BITs. All countries could have been affected by the Cold War, and our results indicate a significantly lower propensity to sign BITs during that era. Our more general measure of BIT period effects (the number of BITs signed in a given year), however, is insignificant in the company of our fairly comprehensive model. Whatever temporal clusters were evident in Figure 1 are accounted for by predictors in our model.

\section{Conclusion}

The use of bilateral investment treaties has grown significantly since the early 1960s. Their growth is especially remarkable given the outright rebellion many hosts have staged against customary law understandings and multilateral codifications of investors' rights that are quite similar to those contained in these proliferating bilateral accords. Why the disjuncture? How can we understand the spread of these promarket agreements across time and space?

The diffusion mechanisms spelled out by Simmons, Dobbin, and Garrett in the introduction to this series of studies suggest a broad range of empirically verifiable hypotheses about movement towards BITs. Both theoretically and empirically, the competition model seems most apt in this case. These treaties are meant to improve conditions under which global capital relocates, prospers, and repatriates. They are also meant to raise the reputational stakes for governments of capitalpoor economies by committing them to respect property and contractual rights of foreign investors and to agree to arbitration-effectively clipping their 
sovereignty-in the event of any disagreement over subsequent investment contracts. There are clearly possibilities here for mutual gain for hosts and investors, though we are agnostic about the global welfare effects of these treaties, given their potential redistributive consequences. We admit that some of the more recent treaties between very poor countries do not square with our straightforward competitive model; nonetheless, the strongest case can be made for a competitive diffusion dynamic in this case.

Let us begin with the project's null hypothesis: that country characteristics or commonly experienced shocks explain the pattern of BIT signings. There was plenty of support in the data for traditional economic explanations. Some of the most important drivers of the spread of BITs are likely factors that drive investment decisions more generally. The pattern of BITs shows that home governments want to secure investments in developing markets that are large, somewhat open, and with high quality labor. On the other hand, BITs are most valuable where political risk is endemic. China, which has concluded a large number of BITs with both rich and poor partners, would be the quintessential BIT partner, according to our model.

We also found strong evidence that dyadic characteristics explain BITs. BITs are much more likely to be negotiated among country pairs of the same culture (at least as measured by shared language) and among country pairs with strong security commitments. But if cultural linkages explain home-host pairs, cultural emulation is much less in evidence among potential hosts. Not one indicator of cultural emulation among hosts had any purchase at all on the adoption of BITs. These cultural arguments may in the end be a more satisfying account available for the growing category of "strange BITs" between highly indebted, capital-poor, noncontiguous country pairs. We know anecdotally that third parties (France, UNCTAD) facilitated many of these agreements, indicating that in many cases external political or cultural forces may be crucial. The strong positive effect of IMF borrowing and alliance relationships on the propensity to sign a BIT also reminds us that a certain degree of coercion may be at play in some cases.

We do not doubt that multiple motives exist for the spread of this form of protection for foreign investors. But the competitive explanation has strong theoretical foundations and is the most consistently supported by the data. First, it was well supported by three different measures of "competitive space": by export market, export product, and workforce/infrastructural quality. When more of a host's closest competitors have signed BITs, that country is much more likely to do so itself. The remarkable consistency across these three highly nuanced measures of competitive space provides strong initial evidence of a tendency to match the policy choices of competitors.

Second, the size and character of markets for FDI have fed the competitive atmosphere in predictable ways. The sheer size of the available pool of investment has greatly raised countries' stakes in securing a share. More BITs are signed when the global capital pool increases. This finding is of course consistent with home countries' concern to protect their investors as well as hosts' desire to increase 
their access. But a second finding much more clearly indicates that the impetus for signing is host-country driven. Our theory of competition among hosts predicts more BITs where the market for FDI is most competitive-the manufacturing sector. We found, in contrast to what theories of obsolescing bargaining would predict, that dependence on extractive industries reduced the probability that a host would make such a commitment.

Finally, a theory of host-driven competition was supported by some of our findings about the qualities associated with those hosts most likely to sign. We expected BITs to be pursued most assiduously by host governments whose domestic institutions render them least able to make credible commitments to protect property rights. When we excluded the possibly confounded "law and order" variable from our analysis, hosts were much more likely to sign if their regime was perceived as corrupt by foreign investors. They were also more likely to sign depending on the nature of their legal institutions. Common law countries-legal systems that some welldocumented empirical work has shown to be associated with better legal protection for property rights - are much less likely to sign than are civil law countries. We recognize there are other reasons for common law countries to be reluctant to enter into international treaty obligations generally, but it remains possible that the differential ability of various legal traditions indigenously to protect property rights is at work as well. In this context, our finding on "law and order" is somewhat puzzling. But we are far less convinced that this indicator captures the domestic institutional guarantees of protection and fairness that foreign direct investors seek.

The diffusion of norms that protect investment has been further advanced by host governments' desire to attract a share of the global capital pool. We have doubts that this phenomenon can be explained by the appeal of liberal ideas alone, for we have witnessed the proliferation of BITs just as multilateral and customary law approaches have foundered. Most governments would prefer to avoid the explicit commitments contained in these treaties; there continue to be few concluded between the wealthiest countries of the world. In some regions, developing countries have tried to coordinate their responses to BITs in hopes of gaining more favorable terms, with notably limited success. In short, we base our conclusions on the importance of competition for capital not just on statistical relationships that show up in the quantitative analysis, but also on the broader context in which our analysis is nested.

BITs are part of a larger process of globalization that has been furthered by the dynamics of competition. This competition is driven by the desire of developing countries to participate in the global capitalist system. But has this uncoordinated strategy of signing away the sovereign right to regulate a growing segment of national economic activity yielded the results developing countries have hoped for? The evidence as to whether BITs actually succeed in attracting capital is unclear on this point. Our research suggests why this may be the case. Competition for capital has important redistributive consequences. The result of the BIT competition may be only minimally improved access to capital at a high cost to national sovereignty. 


\begin{tabular}{|c|c|c|c|c|c|c|}
\hline & Variables & Mean & $\begin{array}{l}\text { Standard } \\
\text { deviation }\end{array}$ & Minimum & Maximum & $\begin{array}{l}\text { Data } \\
\text { sources }\end{array}$ \\
\hline $\begin{array}{l}\text { Dependent variable } \\
\text { Explanatory variables }\end{array}$ & BILATERAL INVESTMENT TREATY (SURVIVAL RATE) ${ }^{1}$ & 0.97 & 0.17 & 0 & 1 & (1) \\
\hline \multirow[t]{7}{*}{ Competition } & BITS AMONG EXPORT MARKET COMPETITORS & 2.79 & 3.72 & 0.00 & 36.57 & (1), (2) \\
\hline & BITS AMONG EXPORT PRODUCT COMPETITORS & 3.70 & 4.12 & 0.00 & 19.20 & (1), (3) \\
\hline & BITS AMONG INFRASTRUCTURE COMPETITORS & 3.41 & 3.84 & 0.03 & 18.21 & (1), (3) \\
\hline & ANNUAL AVERAGE NET FDI INFLOWS ( $\%$ OF GDP) & 1.26 & 1.28 & -1.17 & 3.90 & (3) \\
\hline & HOST EXTRACTIVE INDUSTRIES/EXPORTS & 0.23 & 0.28 & 0.00 & 1.00 & (3) \\
\hline & PERCEPTIONS OF HOST CORRUPTION & 3.27 & 1.23 & 0.00 & 6.00 & (4) \\
\hline & HOST LEGAL TRADITION (COMMON LAW) & 0.32 & 0.47 & 0.00 & 1.00 & (5) \\
\hline \multirow{5}{*}{$\begin{array}{l}\text { Other diffusion } \\
\text { mechanisms }\end{array}$} & BITS AMONG THOSE WITH SAME RELIGION & 2.82 & 3.50 & 0.00 & 32.00 & $(1),(7),(8),(9)$ \\
\hline & BITS AMONG THOSE WITH SAME LANGUAGE & 3.12 & 3.54 & 0.00 & 43.25 & $(1),(7),(8),(9)$ \\
\hline & BITS AMONG THOSE WITH SAME COLONIZER & 2.59 & 3.59 & 0.00 & 56.39 & $(1),(7),(8),(9)$ \\
\hline & LEARNING FROM SUCCESS & -0.15 & 0.22 & -0.59 & 0.17 & (1), (3) \\
\hline & COERCION: HOST USE OF IMF CREDITS & 0.74 & 0.41 & 0.00 & 1.00 & (3) \\
\hline \multirow[t]{10}{*}{ Host country controls } & HOST GDP (LN) & 22.25 & 2.08 & 17.24 & 29.79 & (3) \\
\hline & HOST GDP/CAPITA & 2.21 & 4.70 & 0.00 & 52.71 & (3) \\
\hline & HOST GDP GROWTH & 3.89 & 5.54 & -61.59 & 85.90 & (3) \\
\hline & HOST NET FDI INFLOWS ( $\%$ OF GDP), T- 1 & 1.32 & 3.95 & 0.00 & 145.13 & (3) \\
\hline & HOST ILLITERACY RATE & 0.40 & 0.28 & 0.00 & 1.00 & (3) \\
\hline & HOST CAPITAL ACCOUNT/GDP & -4.74 & 8.54 & -120.60 & 65.30 & (3) \\
\hline & HOST LAW AND ORDER & 2.24 & 1.41 & 0.00 & 6.00 & (4) \\
\hline & HOST DEMOCRACY & -1.71 & 6.85 & -10.00 & 10.00 & (10) \\
\hline & HOST DIPLOMATIC REPRESENTATION & 38.08 & 32.25 & 0.00 & 158.00 & (11) \\
\hline & HOST PRIVATIZATION RECORD & 0.18 & 0.80 & 0.00 & 14.80 & (12) \\
\hline Home country controls & HOME NET FDI OUTFLOWS ( $\%$ OF GDP) & 0.31 & 1.60 & -26.06 & 14.65 & (3) \\
\hline \multirow[t]{4}{*}{ Dyadic controls } & DYADIC TRADE (\% OF HOST'S GDP) & 0.01 & 0.07 & 0.00 & 6.68 & $(2),(3)$ \\
\hline & COMMON COLONIAL HERITAGE & 0.05 & 0.21 & 0.00 & 1.00 & $(7),(8),(9)$ \\
\hline & COMMON LANGUAGE & 0.07 & 0.25 & 0.00 & 1.00 & $(7),(8),(9)$ \\
\hline & ALLIANCE & 0.05 & 0.22 & 0.00 & 1.00 & (13) \\
\hline \multirow[t]{2}{*}{ Common "shocks" } & COLD WAR & 0.72 & 0.45 & 0.00 & 1.00 & - \\
\hline & NUMBER OF BITS GLOBALLY, BY YEAR & 4.47 & 5.14 & 0.00 & 17.72 & (1) \\
\hline
\end{tabular}

Sources: (1) UNCTAD, available at 〈http://www.unctad.org/en/docs/poiteiiad2.en.pdf); (2) International Monetary Fund, Direction of Trade Statistics; (3) World Bank, World Development Indicators; available at 〈http://devdata.worldbank.org.ezp2.harvard.edu/dataonline/); (4) The PRS Group, available at 〈http://www.prsgroup.com//; (5) La Porta, Lopez-De-Silanes, Shleifer, and Vishny 1997 and 1998; (6) Alvarez, Cheibub, Limongi, and Przeworski 1996; Political and Economic Database Codebook, available at 〈http://www.ssc.upenn.edu/ cheibub/data/ACLP_Codebook.PDF); various country Web sites; (7) Countries of the World and Their Leaders Yearbook 2000; (8) Europa World Year Book 1999; (9) Central Intelligence Agency, CIA World Factbook. available at /http://www.odci.gov/cia/publications/ factbook//; (10) Polity IV, available at 〈http://www.cidcm.umd.edu/inscr/polity//; (11) Tagish Diplomatic Directory, available at $\langle$ http://www2.tagish.co.uk/Links/embassy1b.nsf//; (12) Brune, Garrett, and Kogut 2004; (13) Correlates of War (COW) Project, available at $\langle$ http://cow2.la.psu.edu//; Gibler and Sarkees 2004. Note: 1 . Summary statistics for the dependent variable expressed as average survival rates (rate of not signing a BIT). 


\section{References}

Abbott, Kenneth, Robert O. Keohane, Andrew Moravcsik, Anne-Marie Slaughter, and Duncan Snidal. 2000. The Concept of Legalization. International Organization 54 (3):401-19.

Anselin, Luc. 1988. Spatial Econometrics: Methods and Models. Dordrecht, Netherlands: Kluwer Academic.

Baer, Werner. 2001. The Brazilian Economy: Growth and Development. Westport, Conn.: Praeger.

Ball, Clifford A., and Adrian E. Tschoegl. 1982. The Decision to Establish a Foreign Bank Branch or Subsidiary: An Application of Binary Classification Procedures. Journal of Financial and Quantitative Analysis 17 (3):411-24.

Bebchuk, Lucian A. 1984. Litigation and Settlement Under Imperfect Information. Rand Journal of Economics 15 (3):404-15.

Beck, Nathaniel, Kristian Skrede Gleditsch, and Kyle Beardsley. 2006. Space Is More than Geography: Using Spatial Econometrics in the Study of Political Economy. International Studies Quarterly $50(1): 27-44$.

Botero, Juan, Simeon Djankov, Rafael La Porta, Florencio Lopez-de-Silanes, and Andrei Schleifer. 2002. The Regulation of Labor. Available at 〈http://www.econ.ucla.edu/workshops/papers/History/ flopslabor.3.pdf $\rangle$. Accessed 9 July 2006.

Brune, Nancy, Geoffrey Garrett, and Bruce Kogut. 2004. The International Monetary Fund and the Global Spread of Privatization. IMF Staff Papers 51 (2):195-219.

Dolzer, Rudolph. 1981. New Foundations of the Law of Expropriation of Alien Property. American Journal of International Law 75 (3):553-89.

Easterly, William, and Mirvat Sewadeh. 2001. Global Development Network Growth Database. Washington, D.C.: World Bank. Available at 〈http://econ.worldbank.org/WBSITE/EXTERNAL/ EXTDEC/EXTRESEARCH/0, contentMDK:20701055 pagePK:64214825 piPK:64214943 the SitePK:469382,00.html>. Accessed 20 June 2006.

Elkins, Zachary, and Beth Simmons. 2005. On Waves, Clusters, and Diffusion: A Conceptual Framework. Annals of the American Academy of Political and Social Science 598:33-51.

Finger, Joseph M., and M. E. Kreinin. 1979. Measure of Export Similarity and Its Possible Uses. Economic Journal 89 (356):905-12.

Franzese, Robert J., and Jude C. Hays. 2004. Modeling International Diffusion: Inferential Benefits and Methodological Challenges, with an Application to International Tax Competition. WZB Markets and Political Economy Working Paper No. SP II 2004-12. Available at 〈http://ssrn.com/ abstract $=560581\rangle$. Accessed 20 June 2006.

Gibler, Douglas M., and Meredith Reid Sarkees. 2004. Measuring Alliances: The Correlates of War Formal Interstate Alliance Dataset, 1816-2000. Journal of Peace Research 41 (2):211-22.

Gleditsch, Kristian S., and Michael D. Ward. 1999. Interstate System Membership: A Revised List of the Independent States Since 1816. International Interactions 25 (4):393-413.

Gowa, Joanne S. 1994. Allies, Adversaries, and International Trade. Princeton, N.J.: Princeton University Press.

Guzman, Andrew. 1998. Explaining the Popularity of Bilateral Investment Treaties: Why LDCs Sign Treaties That Hurt Them. Virginia Journal of International Law 38:639-89.

__ 2002. International Law: A Compliance Based Theory. California Law Review 90 (6): $1823-88$.

Guzman, Andrew, and Beth A. Simmons. 2005. Power Plays and Capacity Constraints: The Selection of Defendants in WTO Disputes. Journal of Legal Studies 34 (2):557-98.

Hallward-Driemeier, Mary. 2003. Do Bilateral Treaties Attract FDI? Only a Bit ... and They Could Bite. Unpublished manuscript, World Bank, Washington, D.C.

Henisz, Witold J. 2000. The Institutional Environment for Multinational Investment. Journal of Law, Economics, and Organization 16 (2):334-64.

Kimura, Yui. 1989. Firm-Specific Strategic Advantages and Foreign Direct Investment Behavior of Firms: The Case of Japanese Semiconductor Firms. Journal of International Business Studies 20 (2):296-314. 
King, Gary, James Honaker, Anne Joseph, and Kenneth Scheve. 2001. Analyzing Incomplete Political Science Data: An Alternative Algorithm for Multiple Imputation. American Political Science Review 95 (1):49-69.

Kobrin, Stephen J. 1976. The Environmental Determinants of Foreign Manufacturing Investment: An Ex Post Empirical Analysis. Journal of International Business Studies 7 (2):29-42.

. 1980. Foreign Enterprise and Forced Divestment in the LDCs. International Organization 34 (1):65-88.

. 1987. Testing the Bargaining Hypothesis in the Manufacturing Sector in Developing Countries. International Organization 41 (4):609-38.

La Porta, Rafael, Florencio Lopez-De-Silanes, Andrei Shleifer, and Robert W. Vishny. 1997. Legal Determinants of External Finance. Journal of Finance 52 (3):1131-50. 1998. Law and Finance. Journal of Political Economy 106 (6):1113-55.

Lipson, Charles. 1985. Standing Guard: Protecting Foreign Capital in the Nineteenth and Twentieth Centuries. Berkeley: University of California Press.

. 1991. Why Are Some International Agreements Informal? International Organization 45 (4):495-538.

Minor, Michael S. 1994. The Demise of Expropriation as an Instrument of LDC Policy. Journal of International Business Studies 25 (1):177-88.

Neumayer, Eric, and Laura Spess. 2005. Do Bilateral Investment Treaties Increase Foreign Direct Investment to Developing Countries? World Development 33 (10):1567-85.

Pollins, Brian M. 1989. Conflict, Cooperation, and Commerce: The Effect of International Political Interactions on Bilateral Trade Flows. American Journal of Political Science 33 (3):737-61.

Reading, Michael R. 1992. The Bilateral Investment Treaty in ASEAN: A Comparative Analysis. Duke Law Journal 42 (3):679-705.

Simmons, Beth A. Forthcoming. International Human Rights: Law Politics and Accountability. Draft manuscript, Harvard University, Cambridge, Mass.

Simmons, Beth A., and Zachary Elkins. 2004. The Globalization of Liberalization: Policy Diffusion in the International Political Economy. American Political Science Review 98 (1):171-89.

Simmons, Beth, Frank Dobbin, and Geoffrey Garrett. 2006. Introduction: The International Diffusion of Liberalism. International Organization 60 (4):781-810.

Sornarajah, M. 1994. The International Law of Foreign Investment. New York: Cambridge University Press.

Tobin, Jennifer, and Susan Rose-Ackerman. 2003. Foreign Direct Investment and the Business Environment in Developing Countries: The Impact of Bilateral Investment Treaties. Unpublished manuscript, Yale University, New Haven, Conn.

United Nations Conference on Trade and Development (UNCTAD). 1998. Bilateral Investment Treaties in the Mid-1990s. New York: United Nations.

2004. Occasional Note: International Investment Disputes on the Rise. Geneva: UNCTAD.

Vagts, Detlev F. 1987. Foreign Investment Risk Reconsidered: The View from the 1980s. ICSID ReviewForeign Investment Law Journal 2 (1):1-18.

Vandevelde, Kenneth J. 1988. The Bilateral Investment Treaty Program of the United States. Cornell International Law Journal 21 (2):201-76.

Vernon, Raymond. 1971. Sovereignty at Bay: The Multinational Spread of U.S. Enterprises. New York: Basic Books.

. 1977. Storm over the Multinationals: The Real Issues. Cambridge, Mass.: Harvard University Press.

Wasserman, Stanley, and Katherine Faust. 1994. Social Network Analysis: Methods and Applications. Cambridge: Cambridge University Press.

Wheeler, David, and Ashoka Mody. 1992. International Investment Location Decisions. Journal of International Economics 33 (1):57-76. 